\title{
A Sensitivity Study on Nuclide Release from the Near-field of the Pyroprocessed Waste Repository System: Part 1. A Probabilistic Approach
}

\author{
파이로처리 폐기물 처분 시스템 근계 영역 내 핵종 유출 민감도: \\ 제 1 부 확률론적 접근
}

\author{
Youn-Myoung Lee* and Jongtae Jeong \\ Korea Atomic Energy Research Institute, 111 Daedeok-daero 989, Yuseong-gu, Daejeon, Korea \\ 이연명*, 정종태 \\ 한국원자력연구원, 대전광역시 유성구 대덕대로 989 번길 111
}

(Received February 21, 2014 / Revised March 13, 2014 / Approved March 17, 2014)

A parametric sensitivity to the annual exposure dose rate to the farming exposure group has been probabilistically carried out for three principal elements associated with the nuclide transport behavior in the near-field of the pyroprocessed waste repository system. Credit time for both metal and ceramic containers, annual nuclide release rete, and the degree of loss of bentonite buffer around the container are selected as the elements and investigated for important nuclides. All the elements are shown to be sensitive to the results. Methodology studied through this study and the results are expected to make a good feedback to the repository design. As a follow-up study, separated in Part 2, the A-KRS will be deterministically assessed and then compared among each other with the normal, the worst, and the best case scenarios associated with their extreme values these elements could have.

Keywords: A-KRS, Pyroprocessed waste, Safety assessment, Probabilistic sensitivity, GoldSim

파이로처리 방사성폐기물 처분장에서 폐쇄 후 처분장의 성능에 영향을 줄 수 있는 근계 영역 내 세가지 주요 설계 관련 요 소에 대하여 주요 핵종별로 최종 피폭 선량에 주는 민감도를 확률론적인 접근을 통하여 조사하였다. 농축 피폭 집단에 방사 선 피폭을 주는 주요한 핵종들이 처분장에서 유출된 후 처분 시스템 근계 영역 내 다양한 매질을 이동하는 것에 관련되어, 이들 요소가 어느 정도의 영향을 주게 되는지 보기 위하여 처분 용기의 수명, 선원항으로서 처분 용기에서의 연간 핵종 유출 률, 그리고 처분장 주요 인공 방벽으로서 완충재의 손실도 등의 변화에 따른 결과를 검토하였다. 처분장에 대한 결정론적, 확률론적 안전성 평가를 병행 수행하여, 이 세가지 설계 요소의 물리적 변화가 통계적 분포를 가지고 일어난다고 가정하는 확률론적 접근 방법에 따른 연구 결과는 제 1 부의 이 연구에, 그리고 세가지 설계 요소가 가질 수 있는 조합을 서로 다른 시 나리오로서 비교하는 결정론적인 방법으로 접근한 결과는 별도로 제 2 부에 제시하였다. 두 가지 접근 결과와 함께 고려된 인자들에 대하여 모두 결과에 민감한 것으로 나타나 이러한 결과와 방법론은 향후 처분장 설계에 모범적인 피드백을 줄 수 있을 것으로 기대된다.

중심단어: A-KRS, 파이로 처리 폐기물, 안정성평가, 확률론적 민감도, 골드심

*Corresponding Author.

Youn-Myoung Lee, Korea Atomic Energy Research Institute, E-mail: ymlee@kaeri.re.kr, Tel: +82-42-868-2853 
Youn-Myoung Lee et al. : A Sensitivity Study on Nuclide Release from the Near-field of the Pyroprocessed Waste Repository System: Part 1. A Probabilistic Approach

\section{1.서 론}

사용후핵연료를 파이로처리(pyroprocessing) 하면서 발 생되는 2 차 방사성 폐기물을 처분하는 개념으로 A-KRS 처 분시스템이 제안되었다[1]. 사용후핵연료를 직접 영구 처분 하는 개념과 달리 이 개념에 의하면, Fig. 1 에 보이는 것처럼

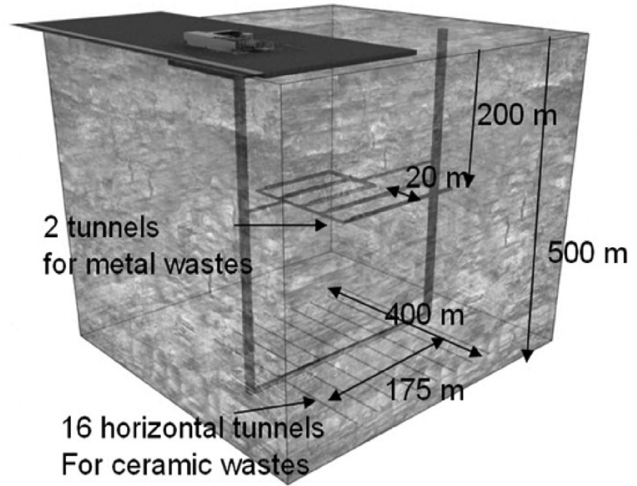

Fig. 1. Conceptual A-KRS repository.
사용후핵연료를 파이로처리하여 발생된 방사성폐기물 두종 류를 지하매질 내에 처분 심도를 달리하여 복층 형태로 건설 되는 2 개의 처분장에 분리 처분하게 된다. 즉, 지표로부터 $200 \mathrm{~m}$ 깊이의 천지층에는 중저준위 방사성 폐기물로 분류되 는 금속폐기물(metal waste)을, $500 \mathrm{~m}$ 깊이의 심지층에는 고 준위 방사성 폐기물로 간주할 수 있는 세라믹 폐기물(ceramic waste)을 처분한다. 굴착된 터널 내에 처분되는 금속 폐기 물은 대개 장반감기를 갖긴 하지만, 붕괴열은 거의 갖지 않 는 핵종을 함유한다. 보다 고 방사능을 가지며 붕괴열도 비 교적 높은 핵종을 갖는 세라믹 폐기물의 경우는 A-KRS 이전 에 고려되었던 사용후 핵연료의 직접 처분과 유사한 스웨덴 의 KBS-3 처분개념[2]으로 심지층에 굴착된 처분 터널 바닥 의 처분공에 폐기물을 처분하는 개념이다. 이러한 처분장을 포함하는 처분시스템은 우리 나라의 지형적 영향을 고려해 볼 때, Fig. 2에 모식적으로 도시한 형태로 될 가능성이 높다.

처분시스템에 대한 성능 평가를 위하여 수행되어야 할 안전성평가에서 지하수의 자연스러운 유동에 따른 정상적 인 핵종 유출 시나리오는, 이전 연구[3 8]에서 일관되게 다 루어진 대로 처분장에 지하수가 침투된 후, 처분 용기가 부 식되어 핵종이 인공방벽으로 유출되고, 완충재나 뒷채움재

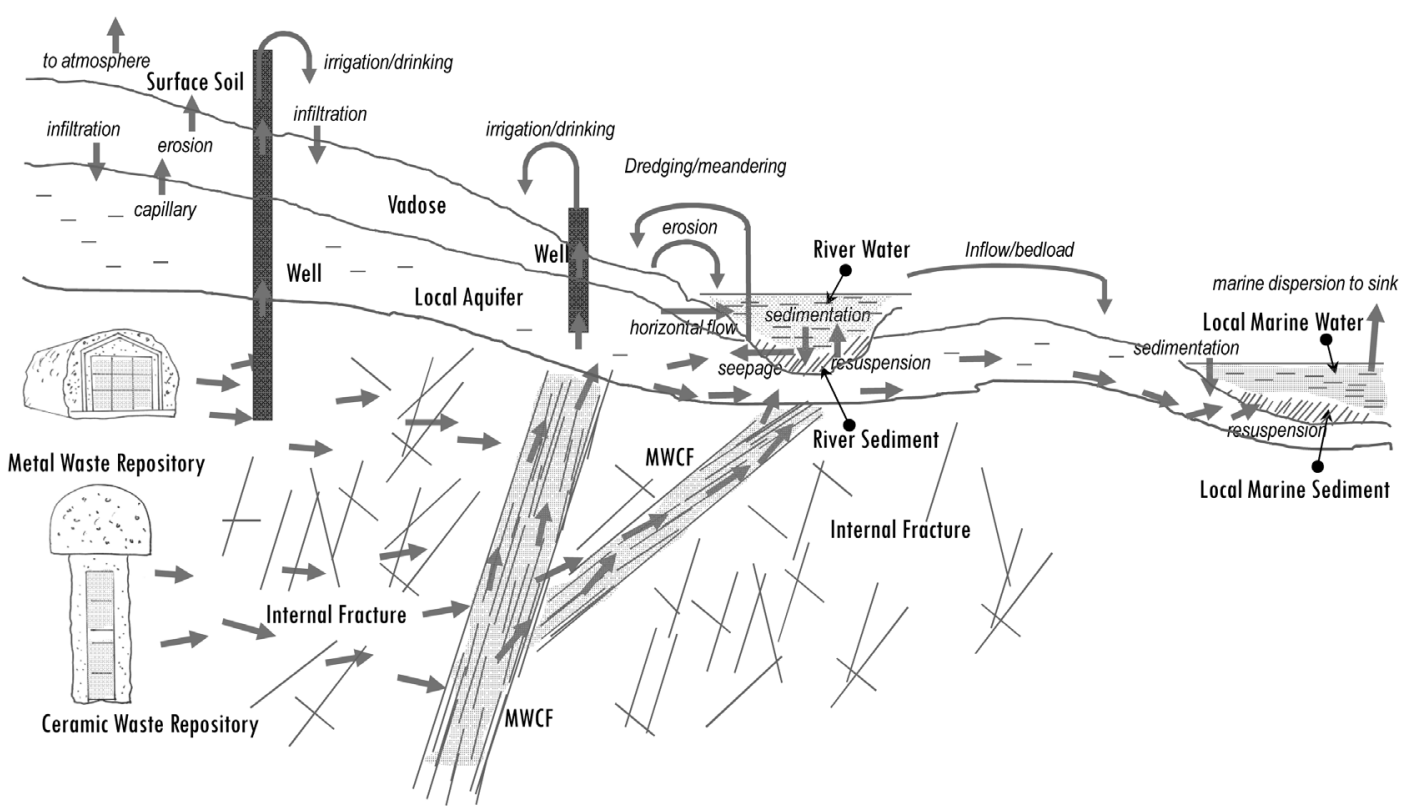

Fig. 2. A-KRS repository system. 
와 같은 인공 방벽의 주된 구성 요소인 처분 시스템 근계 영 역(near-field)을 통하여 그 이동을 계속하게 된다. 이후 처분 장 모암 내 천연 방벽으로 이루어지는 원계 영역(far-field)으 로 들어 온 핵종은 모암 내 균열 네트워크를 형성하는 암반 매질을 지나, 단층이나 규모가 큰 균열과 같이 지하수의 유 동이 급격히, 그리고 대량적으로 이루어지는 선택적 경로로 서의 MWCF(Major Water Conducting Feature or Fault) 지 역을 만나게 되어, 이를 통하여 지하매질과 생태계의 경계 (geosphere-biosphere interface; GBI)를 지나 생태계로 유 출되고, 이후로는 인간 생태 환경에서의 다양한 이동 및 피 폭 경로를 통하여 인간에게 피폭을 주는 것으로 상정할 수 있게 된다.

이 연구의 목적은 이러한 A-KRS에 대하여, 폐쇄 후 처분 장 근계 영역 내에 한정하여 처분장의 성능에 영향을 줄 수 있는 세가지 주요 설계 관련 요소를 인지한 후 이들의 물리 적 변화에 따른 핵종별 최종 피폭 선량에 대한 민감도를 조 사하기 위한 것이다.

인간 환경 내 농축 피폭 집단에 방사선 피폭을 주는 주요 한 핵종들이 처분장에서 유출된 후, 다양한 처분 시스템 내 매질을 이동하는 것에 관련되어 피폭 선량에 주게 되는 영향 을 보기 위한 연구 결과를 다루고, 근계 영역 내 주요한 요소 로서 처분 용기의 수명, 즉 방벽으로서의 신뢰 시간(credit time), 선원항으로서 처분 용기에서의 연간 핵종 유출률(annual nuclide release rate), 그리고 처분장 주요 인공 방벽으 로서 완충재(buffer)의 손실도(degree of loss)에 대한 영향 과 민감도를 확률론적으로 검토하는 연구를 수행한다. 이 와 별도로 제시되는 제 2 부의 후속 연구[9]에서는 이들 세 가지 인자에 대하여 가장 나쁜 경우와 가장 이상적인 조합 을 구성하여 결정론적으로 평가하고 그 결과를 정상적인 경 우의 결과와 비교하여 보았다. 이러한 연구는 향후 처분장의 근계 영역 내 핵종의 유출 및 이동 관련하여 방사성폐기물 처분 시스템 설계에 모범적인 방법론을 제공할 수 있을 것 으로 기대된다.

\section{2. 모델링}

두 개의 처분장을 상이한 형태로 갖는 A-KRS 시스템 내 각 방벽과 매질 별로 핵종의 유출 및 이동에 관한 상세한 모 델링을 먼저 수행 하였다. 폐기물이 처분되는 처분장 자체와 핵종의 유출 및 이동을 저지하고 처분의 안정성을 유지하기
위한 구조물로서 인공방벽까지를 근계 영역으로 한정하는 것이 일반적이라면 자연방벽으로서 모암으로 구성되는 지 하매질은 원계 영역으로 볼 수 있다. 처분장에서 유출된 핵 종이 다양한 경로를 통해, 지하수 내 핵종의 농도 구배를 따 라 확산(diffusion)에 의해, 이동하거나 혹은 지하수의 유동 을 따라 근계 영역을 지나 원계 영역으로 분산(dispersion)과 이류(advection)에 의해 이동하면, 지하영역과 인간 생태 환 경의 경계인 $\mathrm{GBI}$ 를 넘어 지상의 생태계에 이르게 된다. 일련 의 이전 연구[3-8]에서 행해진 대로, 처분 시스템 각 요소 별 로 핵종의 유출과 이동에 관여하는 다양한 특성, 사건, 과정 (feature, event, and process; FEP)을 인지한 후 이를 선별하 면 핵종이 처분장으로부터 유출되어 인간에게 피폭을 주기 까지의 정상 및 비정상 시나리오를 도출할 수 있게 된다. 이 후 시스템을 구성하는 모듈 별로 정상 시나리오에 따른 핵종 의 유출 및 이동을 개념적, 수학적으로 모델링하고, 모사 프 로그램 개발을 위하여 상용의 골드심(GoldSim)[10]을 이용 하여 안정성평가를 수행할 수 있도록 전산 프로그램을 개발 하여 이 연구에서의 확률론적 민감도 평가에 사용하였다. 이 프로그램은 제 2 부의 결정론적 민감도 평가에도 사용된다.

\section{1 금속 폐기물 처분장 개요[1,11]}

금속 폐기물을 처분하기 위한 터널은 지표로부터 $200 \mathrm{~m}$ 깊이의 암반 내에 건설된다. 처분장을 구성하는 매질은 Fig. 3 에서 보는 대로 폴리머 콘크리트 (polymer concrete), 칼슘 벤토나이트 블록의 완충재(Ca-bentonite block buffer), 쇄석 (crushed rock)과 벤토나이트 뒷채움재(bentonite backfill)

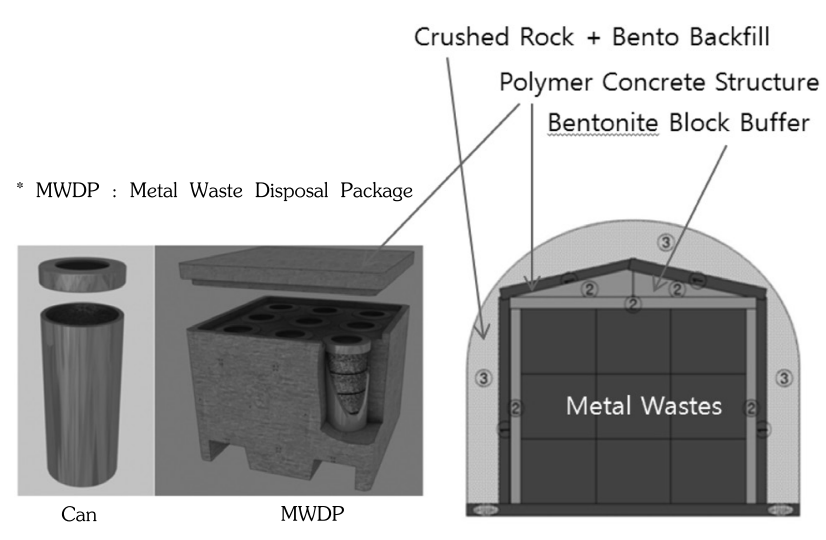

Fig. 3. Disposal concept for metal wastes. 
Youn-Myoung Lee et al. : A Sensitivity Study on Nuclide Release from the Near-field of the Pyroprocessed Waste Repository System: Part 1. A Probabilistic Approach

혼합물 등으로 복합적이다.

처분 용량은 PWR 사용후 핵연료 20,000 tU을 기준으로 하여 파이로 처리된 금속 폐기물은 터널 1 개당 1,235 개씩 의 MWDP(Metal Waste Disposal Packages) 에 담아 2 개의 터널에 모두 처분하는 개념이다. 단순 체적만으로는 금속 폐 기물은 세라믹 폐기물의 약 3 배에 해당되는 양이다. 이러한 금속 폐기물에는 극저 수준의 TRU 핵종이 오염물의 형태로 존재하게 된다.

금속 폐기물은 철제 보관 컨테이너에 포장된 후, 각 변 이 $1.3 \mathrm{~m}$ 의 길이를 갖는 4 면체 폴리머 콘크리트 제 처분 용 기 (package)에 담겨 처분된다. 용기와 터널 내 콘크리트 구 조물 사이, 즉 Fig. 3에서 (2)번에 해당하는 부분은 완충재로 서 벤토나이트 블록이 $36 \mathrm{~cm}$ 의 두께로 채워진다. 이러한 완 충재는 지하수의 조기 침투를 막고 지하수와 함께 유출되는 핵종의 이동을 지연시키며, 처분장의 기계적 안정성을 위한 용도이다.

금속 폐기물 처분 용기로부터 핵종이 유출되는 모델은 이론적으로 다양하게 고려될 수 있는데, 1) 폐기물 조직 물 질의 질량 유출에 따라 핵종도 비례하여 유출되는 상태를 가 정하는 경우의 조화(congruent) 유출, 2) 시간의 흐름에 따 라 동적으로 변화하는 폐기물 표면적에 비례하여 핵종이 유 출되는 것으로 가정하는 표면적 비례 유출, 그리고 3) 조화유 출의 특수한 경우로서, 핵종의 유출이 연간 항상 일정한 비 율로 단순하게 일어난다고 가정하는 일정 유출이 그 것이다.
이 연구에서는 비교적 모호성이 적다고 판단되는 세번째 유 출 모형을 취하여, 핵종은 언제나 $10^{-5} \mathrm{yr}^{-1}$ 의 일정한 비율을 가지며 유출되는 것으로 가정하였다. 물론 핵종에 따라서 용 해도 제한치는 갖는 것으로 하였다.

모든 평가는 Table 1에 보이는 핵종 재고량[3]을 사용하 였다. 최종 피폭 선량에 기여하는 각각의 모든 핵종에 대하여 정상 시나리오 상에서의 핵종 유출 및 이동에 따른 농축 피폭 집단에 대한 피폭 선량을 Fig. 4 와 같이 계산한 후, 이 중에서 $10^{-7} \mathrm{mSv} / \mathrm{yr}$ 이상의 선량률 피크를 가지는 8 개의 핵종 만을 선별하였다. 선별된 8 개의 핵종은 Table 1 에서 보는 대로 ${ }^{14} \mathrm{C}\left(\mathrm{T}_{0.5}=5,701\right.$ 년 $),{ }^{93} \mathrm{Zr}\left(1.53 \times 10^{6}\right.$ 년 $),{ }^{126} \mathrm{Sn}\left(2.23 \times 10^{5}\right.$ 년 $)$, ${ }^{135} \mathrm{Cs}\left(2.30 \times 10^{6}\right.$ 년), ${ }^{229} \mathrm{Th}\left(7,339\right.$ 년), ${ }^{231} \mathrm{~Pa}\left(3.28 \times 10^{4}\right),{ }^{239} \mathrm{Pu}$ (2.41×10 년), 그리고 ${ }^{242} \mathrm{Pu}\left(3.75 \times 10^{5}\right.$ 년) 이다. 이 때 ${ }^{14} \mathrm{C}$ 과 ${ }^{126} \mathrm{Sn}$ 은 금속폐기물에만, ${ }^{229} \mathrm{Th}$ 은 세라믹 폐기물에만 들어 있는 핵종이고, 그 외 나머지 ${ }^{93} \mathrm{Zr},{ }^{135} \mathrm{Cs},{ }^{231} \mathrm{~Pa},{ }^{239} \mathrm{Pu}$, 그리고 ${ }^{242} \mathrm{Pu}$ 는 금속과 세라믹 폐기물에 모두 들어 있는 핵종이다.

이렇게 선별된 핵종에 대해서 세가지 처분장 설계 요소 의 변화에 따른 민감도를 분석해 보고 이를 통해 처분장에 미 칠 수 있는 이들 핵종의 중요도와 잠재적인 위해 정도를 분석 하였다. Table 1 에 보이는 재고량은 금속폐기물의 경우는 금 속 폐기물 처분 터널 1 개에 들어가는 모든 폐기물의 양을 동 등한(equivalent) 한 개의 컨테이너로 간주하여 산출한 값이 다. 즉, 1 개의 금속 폐기물 터널에 단 1 개의 컨테이너가 들 어가는 것으로 가정하였는데 이는 모델링 상 편의를 위한 것

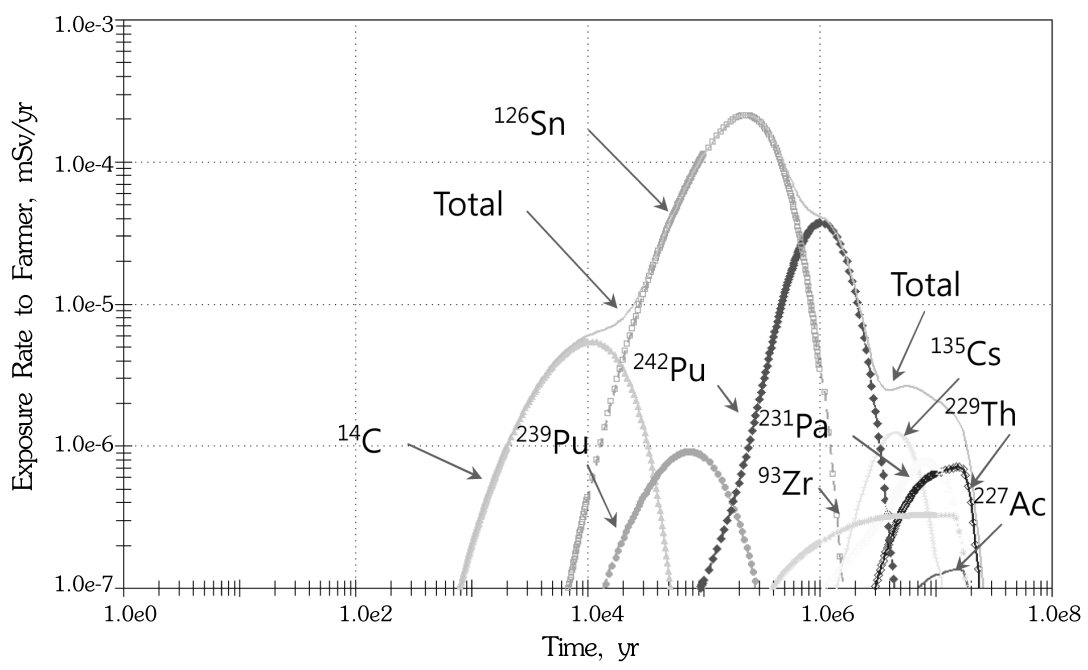

Fig. 4. Exposure dose rate to the farming exposure group under the normal scenario. 
Table 1. Nuclide inventory and dose conversion factor

\begin{tabular}{|c|c|c|c|c|c|}
\hline Nuclide & $\begin{array}{l}\text { Metal Waste Inventory } \\
{[\mathrm{mol} / \mathrm{can}]}\end{array}$ & $\begin{array}{c}\text { Ceramic Waste } \\
\text { Inventory [mole/can] }\end{array}$ & D_ext [Sv h1 / Bq m-3] & D_ing [Sv Bq-1] & D_inh [Sv Bq-1] \\
\hline Ac_227 & 0 & $9.73839 \mathrm{E}-15$ & 0 & $1.10 \mathrm{E}-06$ & $2.20 \mathrm{E}-04$ \\
\hline Am_241 & $6.97 \mathrm{E}-01$ & 0.54842514 & $1.10 \mathrm{E}-15$ & $2.00 \mathrm{E}-07$ & $4.20 \mathrm{E}-05$ \\
\hline Am_243 & $1.31 \mathrm{E}-01$ & 0.104706802 & $2.90 \mathrm{E}-15$ & $2.00 \mathrm{E}-07$ & 4.10E-05 \\
\hline C_14 & $9.29 \mathrm{E}+01$ & 0 & $1.60 \mathrm{E}-20$ & $5.80 \mathrm{E}-10$ & $5.80 \mathrm{E}-10$ \\
\hline Cl_36 & $1.66 \mathrm{E}-03$ & 0 & 0 & $9.30 \mathrm{E}-10$ & 7.30E-09 \\
\hline $\mathrm{Cm} \_245$ & $3.14 \mathrm{E}-03$ & 0.002418193 & $3.20 \mathrm{E}-15$ & $2.10 \mathrm{E}-07$ & $4.20 \mathrm{E}-05$ \\
\hline $\mathrm{Cm} \_246$ & 4.33E-04 & 0.000346542 & $0.00 \mathrm{E}+00$ & $2.10 \mathrm{E}-07$ & 4.20E-05 \\
\hline Cs_135 & $6.58 \mathrm{E}-01$ & 0.95080564 & $2.60 \mathrm{E}-19$ & $2.00 \mathrm{E}-09$ & $9.90 \mathrm{E}-10$ \\
\hline Cs_137 & $5.78 \mathrm{E}-01$ & 0.845011773 & $5.60 \mathrm{E}-14$ & $1.30 \mathrm{E}-08$ & $9.70 \mathrm{E}-09$ \\
\hline I_129 & $2.13 \mathrm{E}-01$ & 0 & $1.10 \mathrm{E}-16$ & $1.10 \mathrm{E}-07$ & $9.60 \mathrm{E}-08$ \\
\hline Nb_94 & $2.74 \mathrm{E}+02$ & 0 & $1.60 \mathrm{E}-13$ & $1.70 \mathrm{E}-09$ & $1.50 \mathrm{E}-09$ \\
\hline Ni_59 & $4.75 \mathrm{E}+03$ & 0 & 0 & $6.30 \mathrm{E}-11$ & $1.30 \mathrm{E}-10$ \\
\hline Ni_63 & $5.51 \mathrm{E}+02$ & 0 & 0 & $1.50 \mathrm{E}-10$ & 4.80E-10 \\
\hline $\mathrm{Np} \_237$ & $3.81 \mathrm{E}-01$ & 0.296420131 & $1.30 \mathrm{E}-15$ & $1.10 \mathrm{E}-07$ & $1.50 \mathrm{E}-05$ \\
\hline $\mathrm{Pa} \_231$ & 3.84E-07 & 4.59383E-11 & $3.70 \mathrm{E}-15$ & $7.10 \mathrm{E}-07$ & $1.40 \mathrm{E}-04$ \\
\hline Pd_107 & $1.99 \mathrm{E}+04$ & $1.67172 \mathrm{E}-16$ & 0 & $3.70 \mathrm{E}-11$ & $8.50 \mathrm{E}-11$ \\
\hline $\mathrm{Pu} \_238$ & $1.29 \mathrm{E}-01$ & 0.101271068 & $1.30 \mathrm{E}-17$ & $2.30 \mathrm{E}-07$ & 4.60E-05 \\
\hline $\mathrm{Pu} \_239$ & $2.64 \mathrm{E}+00$ & 2.061828726 & $6.60 \mathrm{E}-18$ & $2.50 \mathrm{E}-07$ & $5.00 \mathrm{E}-05$ \\
\hline $\mathrm{Pu} \_240$ & $1.28 \mathrm{E}+00$ & 1.015988054 & 0 & $2.50 \mathrm{E}-07$ & $5.00 \mathrm{E}-05$ \\
\hline $\mathrm{Pu} \_241$ & $1.03 \mathrm{E}-01$ & 0.080783661 & 0 & 0 & 0 \\
\hline $\mathrm{Pu} \_242$ & 4.19E-01 & 0.337008372 & 0 & $2.40 \mathrm{E}-07$ & $4.80 \mathrm{E}-05$ \\
\hline Ra_226 & 0 & $2.84865 \mathrm{E}-10$ & $6.00 \mathrm{E}-16$ & $2.80 \mathrm{E}-07$ & $3.50 \mathrm{E}-06$ \\
\hline Ra_228 & 0 & 0 & 0 & 0 & 0 \\
\hline $\mathrm{Rn} \_222$ & 0 & 0 & 0 & 0 & $1.77 \mathrm{E}-10$ \\
\hline $\mathrm{Se} \_79$ & 0 & 0 & $3.60 \mathrm{E}-10$ & $2.40 \mathrm{E}-09$ & $2.50 \mathrm{E}-09$ \\
\hline $\mathrm{Sm}_{-} 151$ & $1.05 \mathrm{E}-02$ & 5.452535555 & $4.60 \mathrm{E}-18$ & $9.80 \mathrm{E}-11$ & $4.00 \mathrm{E}-09$ \\
\hline Sn_126 & $2.48 \mathrm{E}+03$ & 0 & $3.00 \mathrm{E}-15$ & $5.40 \mathrm{E}-09$ & $2.80 \mathrm{E}-08$ \\
\hline Sr_90 & $3.51 \mathrm{E}-01$ & 24.00197242 & 0 & $2.80 \mathrm{E}-08$ & $3.60 \mathrm{E}-08$ \\
\hline Tc_99 & $2.10 \mathrm{E}+01$ & 4.24056E-06 & 0 & $6.40 \mathrm{E}-10$ & $4.00 \mathrm{E}-09$ \\
\hline Th_229 & 0 & $2.93245 \mathrm{E}-10$ & $2.00 \mathrm{E}-15$ & $4.90 \mathrm{E}-07$ & $1.10 \mathrm{E}-04$ \\
\hline Th_230 & $3.75 \mathrm{E}-05$ & $2.41406 \mathrm{E}-06$ & $3.50 \mathrm{E}-17$ & $2.10 \mathrm{E}-07$ & 4.30E-05 \\
\hline Th_232 & 0 & $2.50535 \mathrm{E}-09$ & $1.50 \mathrm{E}-17$ & $2.30 \mathrm{E}-07$ & $4.50 \mathrm{E}-05$ \\
\hline U_233 & $1.44783 \mathrm{E}-05$ & $3.72783 \mathrm{E}-06$ & $5.70 \mathrm{E}-17$ & $5.10 \mathrm{E}-08$ & $3.60 \mathrm{E}-06$ \\
\hline U_234 & 0.436735008 & 0.038540594 & $3.10 \mathrm{E}-17$ & $4.90 \mathrm{E}-08$ & $3.50 \mathrm{E}-06$ \\
\hline U_235 & 13.22854349 & 0.002364337 & $1.10 \mathrm{E}-14$ & 4.70E-08 & $3.10 \mathrm{E}-06$ \\
\hline U_236 & 12.02246827 & 0.00432401 & 0 & 4.70E-08 & $3.20 \mathrm{E}-06$ \\
\hline U_238 & 1692.68363 & $2.48933 \mathrm{E}-05$ & 0 & $4.50 \mathrm{E}-08$ & $2.90 \mathrm{E}-06$ \\
\hline $\mathrm{Zr} \_93$ & 119176.8376 & 0.219053567 & 0 & $1.10 \mathrm{E}-09$ & $1.00 \mathrm{E}-08$ \\
\hline
\end{tabular}


Youn-Myoung Lee et al. : A Sensitivity Study on Nuclide Release from the Near-field of the Pyroprocessed Waste Repository System: Part 1. A Probabilistic Approach

으로, 사실상 이 한 개의 컨테이너에는 1,235 개의 MWDP 가 들어간다는 의미이다.

Fig. 3의 금속 폐기물 처분장 개념에서 보는 대로, 폴리 머 콘크리트로 이루어진 MWDP는 핵종의 이동에 대하여 방 벽의 기능이나 매질의 기능을 따로 갖지는 않는 단순한 용기 로 간주하였다. 처분 용기(container, 그림에서는 Can으로 표시)는 그 수명, 즉 신뢰시간(credit time)으로 100년을 유 지하도록 설계되어 이 시간이 경과하기 전에는 핵종의 유출 이 전혀 일어나지 않는 것으로 하였다. 일정한 기간이 지난 후 용기의 파손 시점을 갖도록 하였지만 이는 일종의 차단막 같은 일시적 방벽일 뿐 설계 개념상 핵종의 이동에 관한 중 간 매질로는 고려하지 않았다.

폴리머 콘크리트 내 처분 용기를 빠져 나온 핵종은, 완충 재와 뒷채움재를 차례로 지나며 매질 내에서 확산 이동을 통 하여 처분장 밖, 원계 영역으로 나가는 것으로 보았다.

근계 영역 내 처분 터널 내에서의 핵종의 이동은, 터널 위 쪽을 한 출구로 하고, 터널 옆과 터널 바닥 쪽을 또 다른 출구 로 하여 그 경로가 모델링 된다. 근계 영역 매질 내에서의 이 동은 이류적 이동을 야기할 만한 지하수의 유동은 존재하지 않는다고 보아 완충재와 뒷채움재 내에서는 확산에 의해서 만 핵종의 이동이 이루어진다고 보고 처분장을 벗어나면서 터널 위쪽의 지하수로 채워진 빈 공간인 크라운(crown)으로 핵종이 들어 오면 크라운과 연결되는 암반 매질 내 균열대를
만나 원계 영역으로의 핵종의 전달이 일어나고, 터널의 옆과 바닥 쪽에서는 바로 균열대를 만나며 핵종의 전달이 일어나 는 것으로 간주하였다.

세라믹 폐기물의 경우에도 금속 폐기물과 마찬가지로 핵 종은 $10^{-5} \mathrm{yr}^{-1}$ 의 일정한 비율을 가지며 유출되는 것으로 가 정하고 마찬가지로 모든 핵종에 대해 용해도 제한치를 부 과하였다.

\section{2 세라믹 폐기물 처분장 개요 $[1,11]$}

세라믹 폐기물은 고준위 방사성 폐기물로서 암반층 내 지하 $500 \mathrm{~m}$ 깊이에 굴착되는 처분 터널의 바닥에 시공되는 처분공(deposition hole)에 처분된다. 이는 금속 폐기물이 터널 내에 처분되는 것과 다른 형태로, 터널에는 폐쇄 후 뒷 채움재가 채워진다.

Fig. 5에서 보이는 대로 철제 컨테이너에 담긴 세라믹 폐 기물은 구리 코팅을 외부에 갖는 주물제 캐니스터로 포장되 어 처분공에 처분된 후, 처분공의 빈 공간은 벤토나이트 완 충재로 채워진다.

이러한 세라믹 폐기물 처분장의 매질은 세라믹 블록(ceramic blocks)과 금속 폐기물의 경우와 동일한 칼슘 벤토나 이트 완충재, 그리고 쇄석과 벤토나이트의 혼합물로 이루어 지는 뒷채움재 등으로 구성된다.
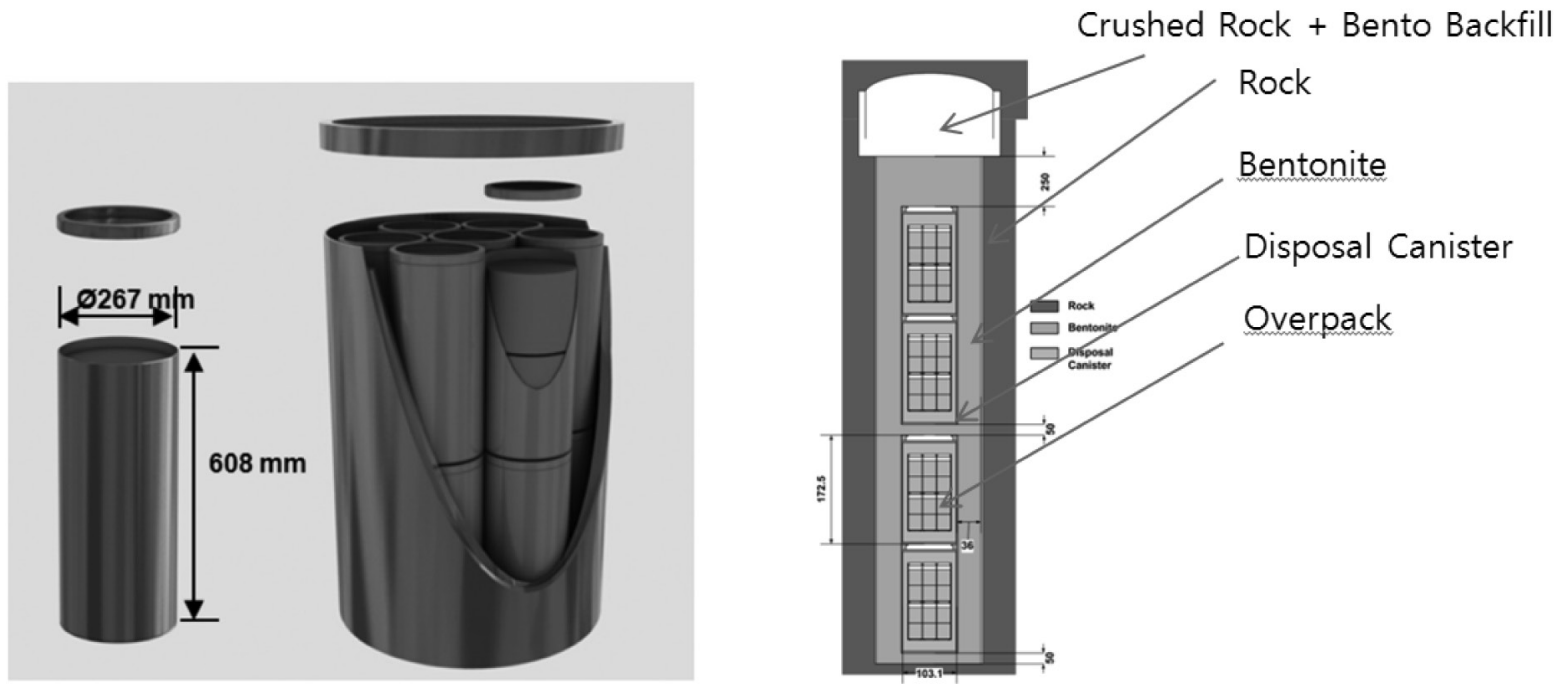

Fig. 5. Disposal concept for ceramic wastes. 
따라서 금속폐기물의 경우와 달리 세라믹폐기물은 보다 복잡한 형태의 터널 매질 내에 처분된다. 근계 영역에서의 핵종 이동 경로도 금속 폐기물의 경우와 매우 다르게 모델링 된다. 처분된 폐기물의 상부와 측면의 완충재 내에서는 금속 폐기물과 마찬가지로 확산에 의한 핵종의 이동이 주로 일어 나지만, 터널과 처분공 인접 암반 내 굴착에 따른 간섭 지대 (Excavated Disturbed Zone; EDZ)에서는 핵종 확산뿐 아니 라 지하수의 유동에 따른 핵종의 분산과 이류에 의한 이동도 함께 고려되었다. 세라믹 폐기물의 경우에서도 $1 \mathrm{~cm}$ 의 두께 를 가지며 부식을 막기 위한 용도의 구리 코팅이나 캐니스터 의 기계적 강도를 유지하기 위한 주철 이너(inner) 모두 핵종 이동에 관여하는 매질로서 다루지는 않는다.

세라믹 폐기물 처분장 내의 각 처분공은 3 가지의 지하 수의 유동 패턴과 관계된다고 보았다. 처분장 상부로부터 지 하수가 처분 터널로 유입되는 경우(outflow), 처분장 하부에 서의 지하수의 수두가 보다 높아 위 방향으로 유입되는 경 우(inflow), 그리고 지하수 유입이 전혀 일어나지 않는 경우 (no flow)가 그것이다. 처분장 건설 시 가능하면 지하수 유 입을 피할 수 있는 부지를 택하게 되므로 "no flow"의 경우가 가장 정상적이긴 하겠지만, 이 연구에서는 보수적 가정으로 세라믹 폐기물이 균열대를 유동하는 지하수에 모두 접촉하 는 "inflow" 시나리오로 선택하였다. 이 때 지하수의 흐름은 처분장 하부에서 상부, 즉 터널 쪽으로 일어나서 폐기된 폐기 물을 통해 오염된 지하수가 $\mathrm{EDZ}$ 를 따라 유동하게 되어 처분 공과 터널 주변 등 모든 $\mathrm{EDZ}$ 내에서 확산과 함께 이류에 의 해서도 핵종의 이동이 이루어지는 것으로 보았다.

세라믹 폐기물의 경우도, PWR 사용후핵연료 20,000 tU 을 기준으로 했을 때, 터널 당 32 개의 처분공을 갖고 각 처분 공 당 2 개의 오버팩(overpack)을 처분하는 것으로 하여 이에 필요한 터널의 개수는 총 16 개에 달하게 된다.

\section{3 원계 영역 및 생태계}

처분장 근계 영역을 빠져 나오면 핵종은 천연 방벽으로 이루어진 원계 영역 내 균열 암반 매질 내에 형성된 균열 네 트워크를 통하여 지하수의 유동을 따라 생태계 쪽으로 그 이 동을 계속하게 된다. GBI는 생태계 내 강의 하저로서, 이 곳 을 통하여 인간 환경으로 전이된 핵종은 생태계 내 지표 경 작지 등 다양한 구획 매질로 유입되고 인간의 농축경작 및 취 락행위와 동식물군의 다양한 섭 생경로를 통하여 최종적으로 인간에게 피폭을 주게 된다. 피폭 대상은 이전의 연구에서 일
관되게 고려된 3가지 피폭 선량 집단[3] 중 대표성을 줄 수 있 는 농축 피폭 집단만을 고려하였다. 균열 네트웍을 갖는 암 반 매질과 $\mathrm{MWCF}$ 가 존재하는 원계 영역 내 비교적 단순한 이 동 모델링과는 달리, 생태계에 대해서는 정상적인 우물과 하 천, 그리고 바다가 존재하는 경우에 대해 물리적 구획을 고려 하고, 다양한 구획 내에서 시간의 흐름에 따라 형성되는 농도 를 통해 다양한 섭생 경로를 갖도록 피폭 모델이 구현되었다.

\section{3. 근계 영역 내 비정상적 핵종 유출}

처분 시스템 내의 핵종의 유출 및 이동은 매질 내의 다양 한 경로를 통하여 이루어진다. 처분 시스템 원계 영역은 아무 런 변화를 주지 않는 것으로 보고 근계 영역에 한정하여 연구 를 진행하였다. 처분시스템은 처분장 내에서 핵종이 가능한 한 오랜 시간 동안 지하수와 격리 되어야 하고, 핵종이 유출 되더라도 유출 정도를 가능한 한 낮추고, 또 유출된 핵종이 매질 내에 가능한 한 지연되어 인간 생태계에 도달하는 시간 을 늦출 수 있도록 방사선적 방벽이 마련되어야 하며, 처분장 의 안정성도 장기간 유지하도록 설계 되어야 한다. 이것이 이 연구에서 다루게 되는 요소들이 인공 방벽 내 처분 시스템 설 계에 관련되어서 주요하다고 판단되는 세 가지, 즉 처분 시스 템 내 폐기물 용기가 지하수의 침투를 차단하고 핵종 유출을 억제할 수 있도록 설계상 주어지는 신뢰시간(credit time), 처 분 용기로부터 핵종이 유출되는 정도로서의 연간 유출률, 그 리고 처분장 근계 영역 내 주요한 방벽으로서의 완충재의 성 능을 연구대상으로 선정한 이유이다.

설계상 처분 용기는 금속 폐기물 용기에 대해서는 100년, 세라믹 폐기물 용기에 대해서는 1,000 년을 정상적인 신뢰시 간으로 부여하였는데, 이러한 용기 신뢰 시간이 변화하는 경 우에 대해 그 결과의 영향이나 민감도가 어떻게 될 것인지 먼 저 검토해 보았다. 즉 금속 폐기물 용기의 신뢰시간에 대해서 는 100 년에서 1,000 년까지로, 세라믹 폐기물 용기에 대해서 는 1,000 년에서 100,000 년까지 변화할 수 있다고 보았다. 주 목할 것은 두 용기 모두 설계 제안치로서 각각 100년과 1,000 년 보다 더 짧아지지는 않는 것으로 하였는데, 이는 이 값들 이 최소한 가져야 할 현실적인 설계 값이라고 판단했기 때문 이다. 따라서 아무리 최악의 경우라도 이 기본적인 용기 신 뢰시간은 유지되며 이 값이 그대로 정상시나리오에 적용되 지만 가장 이상적인 경우는 이 값들이 각각 최대 100배까지 연장될 수 있는 것으로 보았다. 
Youn-Myoung Lee et al. : A Sensitivity Study on Nuclide Release from the Near-field of the Pyroprocessed Waste Repository System: Part 1. A Probabilistic Approach

Table 2. Physical input data [3-8]

\begin{tabular}{|c|c|}
\hline Parameter Name & Value \\
\hline $\begin{array}{c}\text { Number of Canister, PWR/ } \\
\text { Ceramic HLW }\end{array}$ & 11375 \\
\hline Number of canister, CANDU & 2835 \\
\hline \multicolumn{2}{|c|}{ Buffer } \\
\hline Thickness, m & 0.36 \\
\hline Porosity & 0.41 \\
\hline Diffusion coefficient, $\mathrm{m}^{2} / \mathrm{yr}$ & 0.000378 \\
\hline Destiny, $\mathrm{kg} / \mathrm{m}^{3}$ & 1600 \\
\hline Waste form radius, $\mathrm{m}$ & 0.51 \\
\hline \multicolumn{2}{|c|}{ Deep Fractured Rock Mass (@500m) } \\
\hline Flow velocity, $\mathrm{m} / \mathrm{yr}$ & 0.0013 \\
\hline Dispersion coefficient, $\mathrm{m}^{2} / \mathrm{yr}$ & 56.4 \\
\hline Fracture aperture, $\mathrm{m}$ & 0.0001 \\
\hline Fracture Spacing (Deep), $\mathrm{m}$ & 5 \\
\hline Retardation in fracture & 1.0 \\
\hline Matrix diffusion distance, $\mathrm{m}$ & $5.00 \mathrm{E}-01$ \\
\hline Length, m & 419 \\
\hline Matrix porosity & 0.002 \\
\hline Destiny, $\mathrm{kg} / \mathrm{m}^{3}$ & 2650 \\
\hline Diffusion coefficient, $\mathrm{m}^{2} / \mathrm{yr}$ & $1.00 \mathrm{E}-06$ \\
\hline Mass gradient, $\%$ & 5 \\
\hline $\begin{array}{l}\text { Hydraulic conductivity of the } \\
\text { rock mass at } 500 \mathrm{~m}, \mathrm{~m} / \mathrm{s}\end{array}$ & $1.00 \mathrm{E}-10$ \\
\hline \multicolumn{2}{|c|}{ Intermediate Fractured Rock Mass (@200m) } \\
\hline \multicolumn{2}{|l|}{ Flow velocity, $\mathrm{m} / \mathrm{yr}$} \\
\hline Dispersion coefficient, $\mathrm{m}^{2} / \mathrm{yr}$ & One tenth of the length \\
\hline Fracture aperture, $\mathrm{m}$ & 4.00E-05 \\
\hline Fracture Spacing (Intermediate) & 5 \\
\hline Retardation in fracture & 1.0 \\
\hline Matrix diffusion distance, $\mathrm{m}$ & $5.00 \mathrm{E}-01$ \\
\hline $\begin{array}{l}\text { Length in Intermediate Shallow } \\
\text { Rock, } m\end{array}$ & 533 \\
\hline Matrix porosity & 0.002 \\
\hline Destiny, $\mathrm{kg} / \mathrm{m}^{3}$ & 2650 \\
\hline
\end{tabular}

\begin{tabular}{|c|c|}
\hline Parameter Name & Value \\
\hline \multicolumn{2}{|l|}{ Diffusion coefficient, $\mathrm{m}^{2} / \mathrm{yr}$} \\
\hline $\begin{array}{l}\text { Hydraulic conductivity of the } \\
\text { rock mass at } 200 \mathrm{~m}, \mathrm{~m} / \mathrm{s}\end{array}$ & $1.00 \mathrm{E}-08$ \\
\hline \multicolumn{2}{|c|}{ MWCF (@500m) } \\
\hline Flow velocity, $\mathrm{m} / \mathrm{yr}$ & 20 \\
\hline Dispersion coefficient, $\mathrm{m}^{2} / \mathrm{yr}$ & One tenth of the length \\
\hline Fracture aperture, $\mathrm{m}$ & 0.001 \\
\hline \multicolumn{2}{|l|}{ Fracture Spacing, m } \\
\hline Retardation in fracture & 1 \\
\hline Matrix diffusion distance, $\mathrm{m}$ & 1 \\
\hline Length, m & 468 \\
\hline Matrix porosity & 0.002 \\
\hline Destiny, $\mathrm{kg} / \mathrm{m}^{3}$ & 2650 \\
\hline \multicolumn{2}{|l|}{ Diffusion coefficient, $\mathrm{m}^{2} / \mathrm{yr}$} \\
\hline Hydraulic conductivity, $\mathrm{m} / \mathrm{s}$ & $2.00 \mathrm{E}-08$ \\
\hline MWCF fracture width, $\mathrm{m}$ & $5.00 \mathrm{E}+02$ \\
\hline \multicolumn{2}{|c|}{ MWCF (@200m) } \\
\hline Flow velocity, m/yr & 13.8 \\
\hline \multicolumn{2}{|l|}{ Dispersion coefficient, $\mathrm{m}^{2} / \mathrm{yr}$} \\
\hline Fracture aperture, $\mathrm{m}$ & 0.001 \\
\hline \multicolumn{2}{|l|}{ Fracture Spacing, $\mathrm{m}$} \\
\hline Retardation in fracture & 1 \\
\hline Matrix diffusion distance, $\mathrm{m}$ & 1 \\
\hline Length & 320 \\
\hline \multicolumn{2}{|l|}{ Matrix porosity } \\
\hline \multicolumn{2}{|l|}{ Destiny, $\mathrm{kg} / \mathrm{m}^{3}$} \\
\hline \multicolumn{2}{|l|}{ Diffusion coefficient, $\mathrm{m}^{2} / \mathrm{yr}$} \\
\hline Hydraulic conductivity, $\mathrm{m} / \mathrm{s}$ & $2.00 \mathrm{E}-08$ \\
\hline \multicolumn{2}{|c|}{ Backfill } \\
\hline Diffusion coefficient, $\mathrm{m}^{2} / \mathrm{yr}$ & $3.15 \mathrm{E}-03$ \\
\hline \multicolumn{2}{|l|}{ Groundwater } \\
\hline Pure diffusion coefficient, $\mathrm{m}^{2} / \mathrm{yr}$ & 0.032 \\
\hline $\begin{array}{l}\text { Plume Width at the Biosphere in } \\
\text { MWCF, } m\end{array}$ & 2400 \\
\hline
\end{tabular}


금속폐기물이나 세라믹 폐기물 모두 실험을 통하여 보 다 정확한 유출 메커니즘이 규명되어야 하나 현재로서는 이 론적으로 모델링된 유출 모형을 사용하고 있다. 전술하였듯 이 이 연구에서는 보수적이면서 가장 단순한 형태로서의 선 형적인 연간 단순 유출률을 고려하는 것이 이 연구의 목적 상 타당해 보인다. 따라서 두 폐기물 모두에 대하여 정상적 일 때 연간 $10^{-5} \mathrm{yr}^{-1}$ 의 단순 유출률을 갖는 것으로 하고, 최악 의 경우 이 값은 $10^{-4} \mathrm{yr}^{-1}$ 으로 증가할 수 있다고 보았다. 반면 이상적인 경우로서는 $10^{-6} \mathrm{yr}^{-1}$ 까지 유출률이 줄어들 수 있다 고 보았다.

처분장을 구성하는 주요한 인공방벽으로서 완충재는 방 사선적인 측면에서만 핵종의 이동과 저지의 관점에서 그 기 능의 변화, 즉 열화나 소실에 따른 방사선적 영향과 그 민감 도에 한정하여 고찰해 보았다. 처분장이 폐쇄된 이후 완충재
의 기능을 유지하지 못하고 그 기능을 상실하는 손실도로서 의 척도는, 완충재의 공극률(porosity)에 전적으로 선형적인 관계를 갖는 것으로 가정하였다. 즉 완충재의 공극률이 0 에 가까워지는 경우가 핵종의 이동 저지 목적상 가장 이상적이 라 보고, 물리적인 완충재 소실 자체나 완충재의 장벽으로서 의 기능을 모두 소실하는 경우 그 공극률은 1.0 에 가까워지 는 것으로 보았다.

한편 이러한 요소들의 민감도와 영향을 평가하기 위하 여 계산에 사용한 각종 입력 자료는 Table 2 와 3 에 기술해 두었다.

\section{1 처분 용기 신뢰 시간}

Table 4에서 보는 대로 금속폐기물의 용기에 대해서는

Table 3. Distribution coefficient (Kd) and solubility limit (Cs)[3-8]

\begin{tabular}{|c|c|c|c|c|c|c|c|}
\hline Nuclide & Buffer $\left[\mathrm{m}^{3} / \mathrm{kg}\right]$ & $\operatorname{Rock}\left[\mathrm{m}^{3} / \mathrm{kg}\right]$ & $\begin{array}{c}\text { Surface Soil } \\
{\left[\mathrm{m}^{3} / \mathrm{kg}\right]}\end{array}$ & Vadose $\left[\mathrm{m}^{3} / \mathrm{kg}\right]$ & $\begin{array}{c}\text { River Sediment } \\
{\left[\mathrm{m}^{3} / \mathrm{kg}\right]}\end{array}$ & $\begin{array}{l}\text { Marine Sedi- } \\
\text { ment }\left[\mathrm{m}^{3} / \mathrm{kg}\right]\end{array}$ & $\begin{array}{c}\text { Cs (Reducing) } \\
{\left[\mathrm{mol} / \mathrm{m}^{3}\right]}\end{array}$ \\
\hline Ac & $5.00 \mathrm{E}+00$ & $1.00 \mathrm{E}+01$ & $4.50 \mathrm{E}-01$ & $4.50 \mathrm{E}-01$ & $1.00 \mathrm{E}+02$ & $2.00 \mathrm{E}+03$ & $1.00 \mathrm{E}-04$ \\
\hline $\mathrm{Am}$ & $5.00 \mathrm{E}+00$ & $1.00 \mathrm{E}+01$ & $2.00 \mathrm{E}+00$ & $8.00 \mathrm{E}+00$ & $1.00 \mathrm{E}+02$ & $2.00 \mathrm{E}+03$ & $1.00 \mathrm{E}-04$ \\
\hline $\mathrm{C}$ & 0 & $1.00 \mathrm{E}-03$ & 0 & 0 & 0 & 0 & $1.00 \mathrm{E}+00$ \\
\hline $\mathrm{Cl}$ & 0 & 0 & 0 & 0 & 0 & 0 & $7.00 \mathrm{E}+03$ \\
\hline $\mathrm{Cm}$ & $5.00 \mathrm{E}+00$ & $1.00 \mathrm{E}+01$ & $4.00 \mathrm{E}+00$ & $4.00 \mathrm{E}+00$ & $1.00 \mathrm{E}+02$ & $2.00 \mathrm{E}+03$ & $1.00 \mathrm{E}-04$ \\
\hline Cs & $6.60 \mathrm{E}-01$ & $5.20 \mathrm{E}-02$ & $2.70 \mathrm{E}-01$ & $2.70 \mathrm{E}-01$ & $2.00 \mathrm{E}+00$ & $3.00 \mathrm{E}+00$ & 4000 \\
\hline I & $7.40 \mathrm{E}-03$ & 0 & 0 & 0 & 0 & 0 & 4000 \\
\hline $\mathrm{Nb}$ & $1.00 \mathrm{E}+00$ & $1.00 \mathrm{E}+00$ & $1.60 \mathrm{E}-01$ & $1.60 \mathrm{E}-01$ & $1.00 \mathrm{E}+01$ & $1.00 \mathrm{E}+01$ & 0.0001 \\
\hline $\mathrm{Ni}$ & $7.00 \mathrm{E}-01$ & $1.20 \mathrm{E}-01$ & 0 & 0 & 0 & 0 & $5.00 \mathrm{E}-04$ \\
\hline $\mathrm{Np}$ & $3.00 \mathrm{E}+00$ & $1.70 \mathrm{E}-01$ & $4.10 \mathrm{E}-03$ & 4.10E-03 & $5.00 \mathrm{E}-01$ & $2.00 \mathrm{E}+00$ & $2.00 \mathrm{E}-05$ \\
\hline $\mathrm{Pa}$ & $3.00 \mathrm{E}-01$ & $1.00 \mathrm{E}+00$ & $5.40 \mathrm{E}-01$ & $5.40 \mathrm{E}-01$ & $5.00 \mathrm{E}+03$ & $5.00 \mathrm{E}+03$ & $5.00 \mathrm{E}-05$ \\
\hline $\mathrm{Pd}$ & $1.00 \mathrm{E}-02$ & $1.00 \mathrm{E}-01$ & $5.50 \mathrm{E}-03$ & $5.50 \mathrm{E}-03$ & $2.00 \mathrm{E}+00$ & $5.00 \mathrm{E}+01$ & $1.00 \mathrm{E}-05$ \\
\hline $\mathrm{Pu}$ & $3.00 \mathrm{E}+00$ & $4.00 \mathrm{E}-03$ & $5.40 \mathrm{E}-01$ & $5.40 \mathrm{E}-01$ & $1.00 \mathrm{E}+02$ & $2.00 \mathrm{E}+03$ & $5.00 \mathrm{E}-06$ \\
\hline $\mathrm{Ra}$ & $1.00 \mathrm{E}-02$ & $1.30 \mathrm{E}+00$ & $4.90 \mathrm{E}-01$ & $4.90 \mathrm{E}-01$ & $1.00 \mathrm{E}+00$ & $5.00 \mathrm{E}+00$ & $1.00 \mathrm{E}-03$ \\
\hline $\mathrm{Rn}$ & 0 & 0 & 0 & 0 & 0 & 0 & $-1.00 \mathrm{E}+00$ \\
\hline $\mathrm{Se}$ & $3.00 \mathrm{E}-03$ & $8.30 \mathrm{E}-04$ & 0 & 0 & 0 & 0 & 0.0001 \\
\hline $\mathrm{Sm}$ & $1.00 \mathrm{E}+00$ & $1.00 \mathrm{E}+00$ & $2.40 \mathrm{E}-01$ & $2.40 \mathrm{E}-01$ & $1.00 \mathrm{E}+02$ & $2.00 \mathrm{E}+03$ & 0.0001 \\
\hline Sn & $3.00 \mathrm{E}+00$ & $2.00 \mathrm{E}-02$ & $1.30 \mathrm{E}-01$ & $1.30 \mathrm{E}-01$ & $1.00 \mathrm{E}+01$ & $1.00 \mathrm{E}+01$ & $5.00 \mathrm{E}-04$ \\
\hline $\mathrm{Sr}$ & $1.20 \mathrm{E}-02$ & $1.00 \mathrm{E}-02$ & 0 & 0 & 0 & 0 & $1.00 \mathrm{E}+01$ \\
\hline $\mathrm{Tc}$ & $1.00 \mathrm{E}-01$ & $1.00 \mathrm{E}+00$ & $1.40 \mathrm{E}-04$ & $1.40 \mathrm{E}-04$ & $1.00 \mathrm{E}-01$ & $1.00 \mathrm{E}-01$ & $1.00 \mathrm{E}-05$ \\
\hline Th & $3.00 \mathrm{E}+00$ & $5.00 \mathrm{E}+00$ & $3.00 \mathrm{E}+00$ & $3.00 \mathrm{E}+00$ & $5.00 \mathrm{E}+03$ & $5.00 \mathrm{E}+03$ & $5.00 \mathrm{E}-05$ \\
\hline $\mathrm{U}$ & $1.70 \mathrm{E}-01$ & $4.30 \mathrm{E}-02$ & $3.30 \mathrm{E}-02$ & $3.30 \mathrm{E}-02$ & $5.00 \mathrm{E}-02$ & $5.00 \mathrm{E}-01$ & $1.00 \mathrm{E}-05$ \\
\hline $\mathrm{Zr}$ & $2.00 \mathrm{E}+00$ & $2.00 \mathrm{E}-01$ & $6.00 \mathrm{E}-01$ & $6.00 \mathrm{E}-01$ & $1.00 \mathrm{E}+01$ & $1.00 \mathrm{E}+01$ & $1.00 \mathrm{E}-05$ \\
\hline
\end{tabular}


Youn-Myoung Lee et al. : A Sensitivity Study on Nuclide Release from the Near-field of the Pyroprocessed Waste Repository System: Part 1. A Probabilistic Approach

100년과 10,000년 사이에서, 그리고 세라믹폐기물의 용기에 대해서는 1,000 과 100,000 년 사이에서 모두 균등분포 (uniform distribution) 를 따르는 것으로 가정하여 확률론적 평 가를 수행하였다. 그 결과는 Fig. 6에 보였다.

몬테칼로 계산을 위한 샘플링 수는 충분하다고 판단되 는 100 회로 하였고 효율적인 구현을 위해 라틴 초입방추출 (Latin hypercube) 샘플링 방법을 사용하였다.

결과로 보여지는 그림에서 보면 초기에 농축 피폭 집단 에 대한 연간 피폭 선량률의 변화가 매우 심하게 나타나는 것 을 알 수 있다. 이러한 변화는, Fig. 7 (a)에 도시한 ${ }^{14} \mathrm{C}$ 에 의해 주로, 그리고 Fig. 7 (c)에 보인 ${ }^{126} \mathrm{Sn}$ 에 의해 일부 기여된 것이 다. Fig. 7(b), 7(d) 7(h)에 보인 그 외 다른 핵종들은 용기의 신뢰 시간에 대해서 그다지 민감하지 않은 것으로 나타나고 있음을 알 수 있다. Table 3 에서 보이는 대로 ${ }^{14} \mathrm{C}$ 는 다른 핵종 들과 달리 완충재 내의 분배 계수 $(\mathrm{Kd})$ 값을 전혀 갖지 않아 이 매질 내를 이동하는 동안 지연이 이루어지지 않는 데다, 5,701 년이라는 상대적으로 짧은 반감기 때문에 이런 결과가 나타나는 것으로 보인다. 반면 ${ }^{126} \mathrm{Sn}$ 의 경우는 높은 $\mathrm{Kd}$ 값도 갖고 반감기도 20 만 년이 넘긴 하지만 Table 1 에서 보는 대 로 재고량 자체가 상대적으로 매우 높아 이러한 결과가 나타 나는 것으로 보인다. 그러나 가장 높은 피크치를 주는 ${ }^{126} \mathrm{Sn}$ 은 긴 반감기 때문에 피크치 자체에 대한 민감도는 그리 높 지는 않게 나타나는 것을 알 수 있다.

용기 신뢰시간에 대한 민감도를 보기 위하여 별도로 신 뢰시간과 농축피폭 집단에 주는 선량률의 상관관계도 Fig. 8 에 도시하여 보았다. 그림에서 $\mathrm{y}$ 축은 각 폐기물 용기의 신뢰 시간에 대한 지연 정도를 1 에서 100 배 사이로 나타낸 것이 다. 이는 금속 폐기물의 경우 정상적으로 100 년의 용기 수명 을 갖게 되지만 지연정도 1 100을 적용했을 때 100년에서 10,000 년 사이의 용기 수명을 갖게 되고, 세라믹폐기물의 경 우는 정상적으로는 1,000 년의 용기 수명을 갖지만 이 역시 지연정도 1 100을 적용하면 1000년에서 100,000 년 사이의 용기 수명을 갖는다는 의미가 된다.

금속폐기물의 경우 용기 신뢰 시간에 대한 상관 관계가

Table 4. Waste package failure time distribution

\begin{tabular}{ccc}
\hline Waste Type & Nominal, yr & Distribution, yr \\
\hline Metal Waste & 100 & $\begin{array}{c}\text { Uniform }\{100 \times(1, \\
100)\}\end{array}$ \\
\hline Ceramic Waste & 1,000 & $\begin{array}{c}\text { Uniform }\{1,000 \times(1, \\
100)\}\end{array}$ \\
\hline
\end{tabular}

어느 정도 나타나고 있으나(Fig. 8(a)), 세라믹 폐기물의 용 기에 대한 피크 값의 민감도는 그리 높지 않게 나타나고 있 는 것을 알 수 있는데(Fig. 8(b)), 이는 세라믹 폐기물내의 핵 종은 금속 폐기물의 핵종들과 달리 선량 피크치에는 그다지
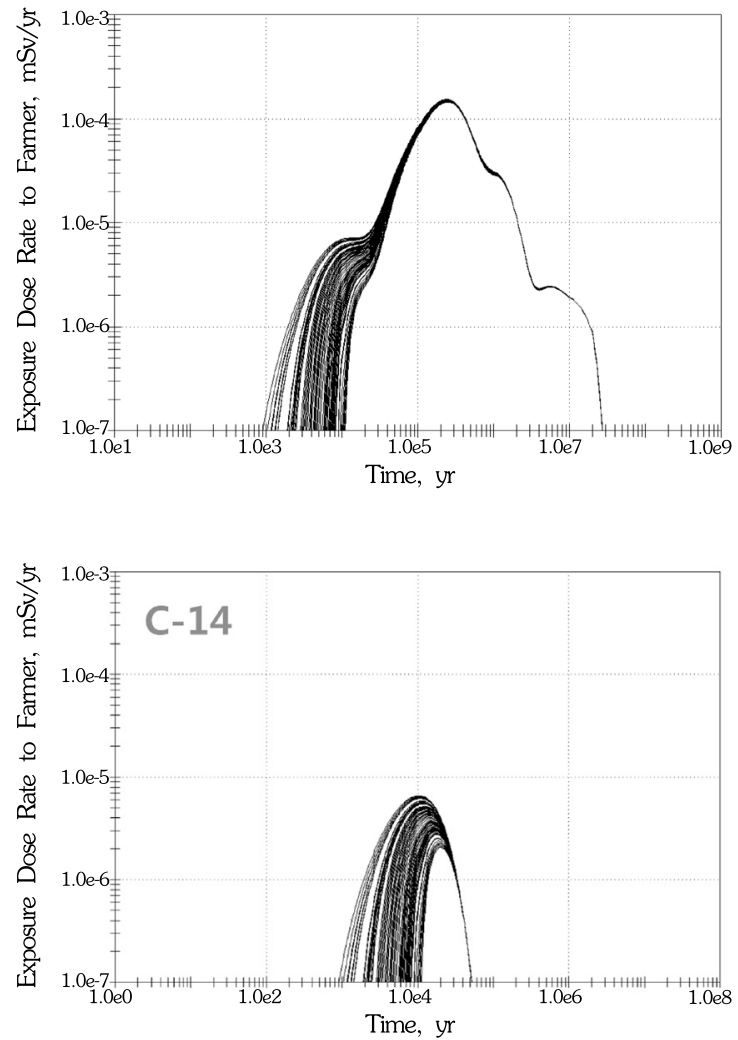

(a)

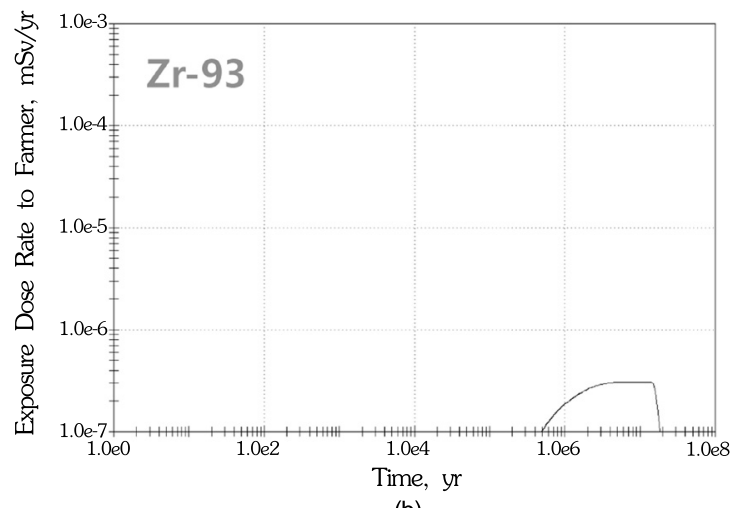

(b)

Fig. 6. All 100 realizations of the total exposure dose rate when the container credit time varies, due to all the nuclides both in the metal and ceramic waste repositories to the farming exposure group. 
Youn-Myoung Lee et al. : A Sensitivity Study on Nuclide Release from the Near-field of the Pyroprocessed Waste Repository System: Part 1. A Probabilistic Approach
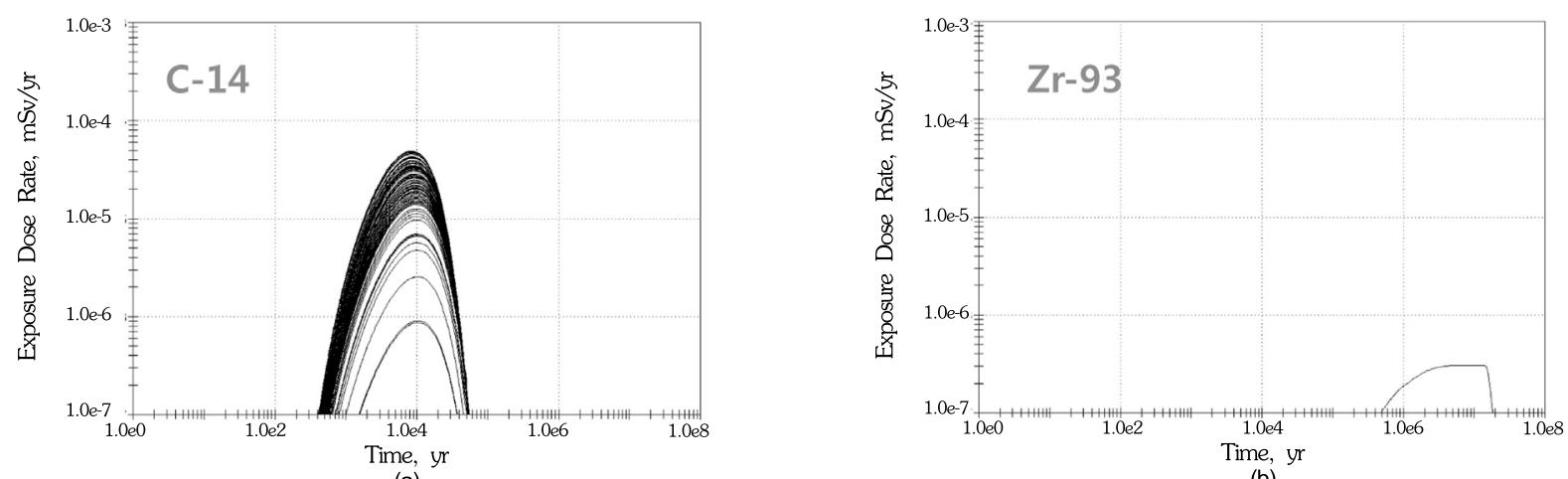

(a)
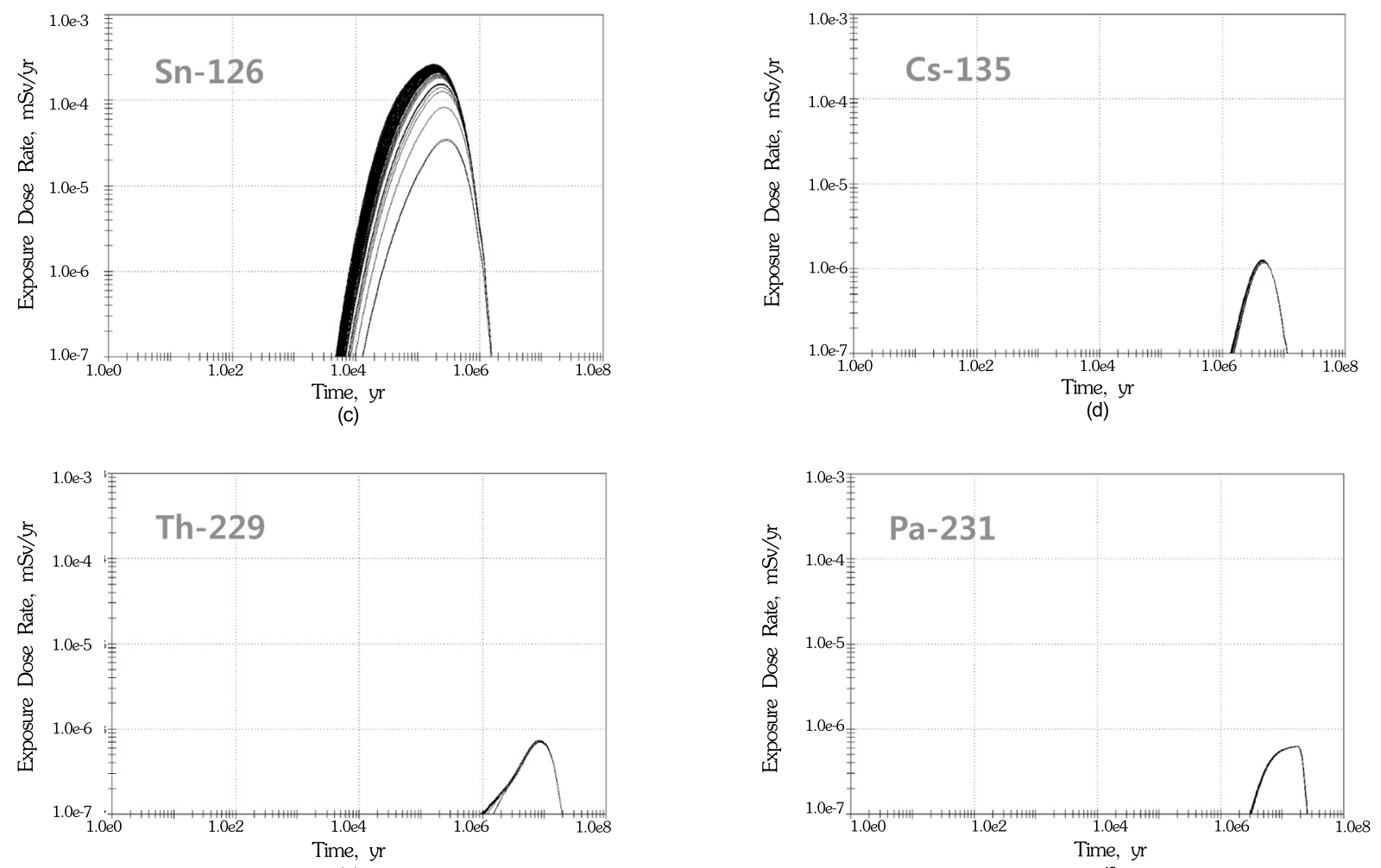

(e)
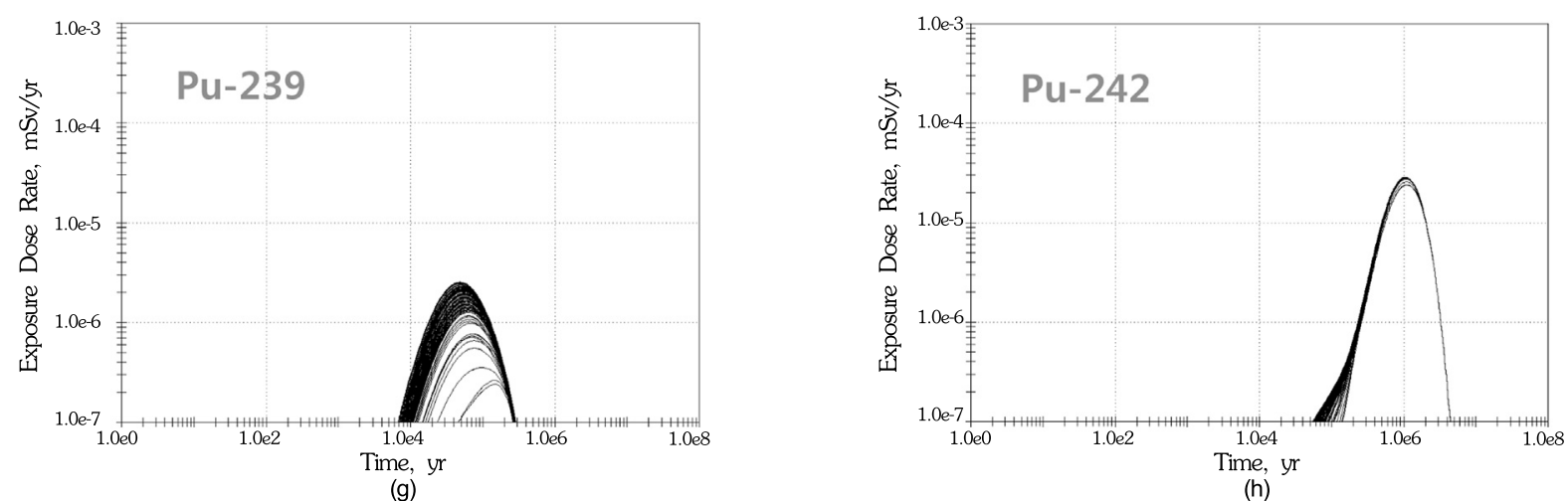

Fig. 7. Realizations of the total exposure dose rate due to each nuclide in the metal and ceramic waste repositories to the farming exposure group. 
Youn-Myoung Lee et al. : A Sensitivity Study on Nuclide Release from the Near-field of the Pyroprocessed Waste Repository System: Part 1. A Probabilistic Approach

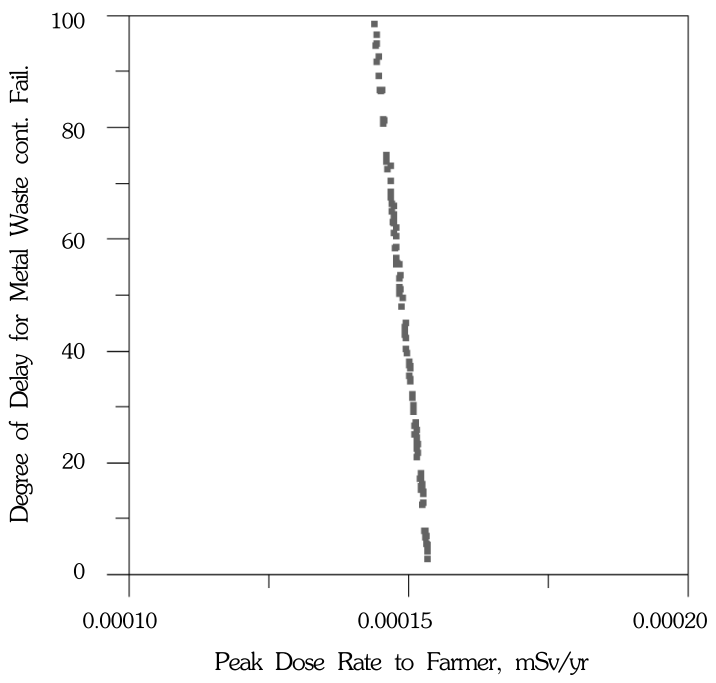

(a)

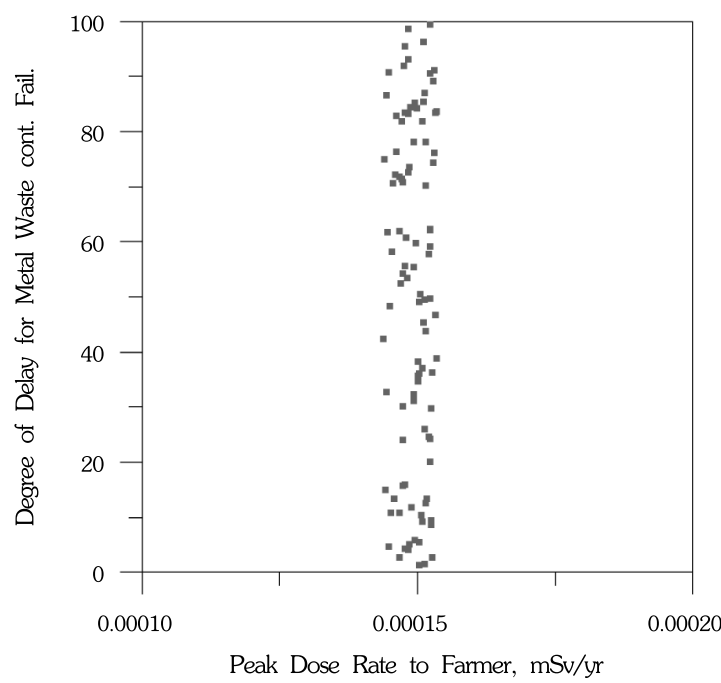

(b)

Fig. 8. Sensitivity of the degree of delay for waste container failure to the dose rate which varies between 1 and 100 for the metal (a) and ceramic (b) waste containers.

기여하지 못하기 때문이다.

\section{2 핵종 유출률}

정상적인 핵종 유출률 대신, Table 5 에서와 같이 금속 폐 기물과 세라믹 폐기물에 대해 통계적으로 $10^{-6} \mathrm{yr}^{-1}$ 와 $10^{-4} \mathrm{yr}^{-1}$ 사이에서 균등 분포를 가지고 변화하는 것으로 가정하여 확 률론적 계산을 수행하였다.

그 결과로서 나타난 Fig. 9에서 보면, 이 역시 보다 확장 된 시간에 걸쳐 연간 피폭 선량률의 변화가 심하게 나타나고 있는 것을 알 수 있다. 즉 이전의 용기 신뢰시간의 경우와 다 르게 이러한 변화가 초기뿐 아니라 이후 피크치에 이르러서 도 광범위하게 나타나고 있는 것을 알 수 있다. 이러한 결과 는 주로 Fig. $10(\mathrm{a}), 10(\mathrm{c})$, 그리고 $10(\mathrm{~g})$ 에 나타낸 대로 각각 ${ }^{14} \mathrm{C},{ }^{126} \mathrm{Sn}$, 그리고 ${ }^{239} \mathrm{Pu}$ 의 기여에 의한 것임을 알 수 있다. 앞 의 두 핵종은 신뢰 시간의 경우 보다도 피크치의 변화가 더 극심한 것을 알 수 있고, 그 외에 반감기가 20 년 정도인 ${ }^{239} \mathrm{Pu}$ 의 두드러진 등장은 폐기물 내에 이 핵종의 재고량이 많은데 다 반감기가 상대적으로 짭은 핵종들이, 핵종 유출률에 대해 상대적으로 보다 더 민감할 수 있기 때문에 전체적으로 피크 치가 매우 민감하게 변화한다는 것으로 보여진다.

핵종의 연간 유출률에 대한 민감도를 보기 위하여 신뢰 시간과 농축피폭 집단에 주는 선량률의 상관관계도 Fig. 11
Table 5. Fixed nuclide release rate distribution

\begin{tabular}{ccc}
\hline Waste Type & Nominal, $\mathrm{yr}^{-1}$ & Distribution, $\mathrm{yr}^{-1}$ \\
\hline Metal Waste & $10^{-5}$ & $\begin{array}{c}\text { Uniform }\left\{10^{-5} \times(0.1,\right. \\
10)\}\end{array}$ \\
\hline Ceramic Waste & $10^{-5}$ & $\begin{array}{c}\text { Uniform }\left\{10^{-5} \times(0.1,\right. \\
10)\}\end{array}$ \\
\hline
\end{tabular}

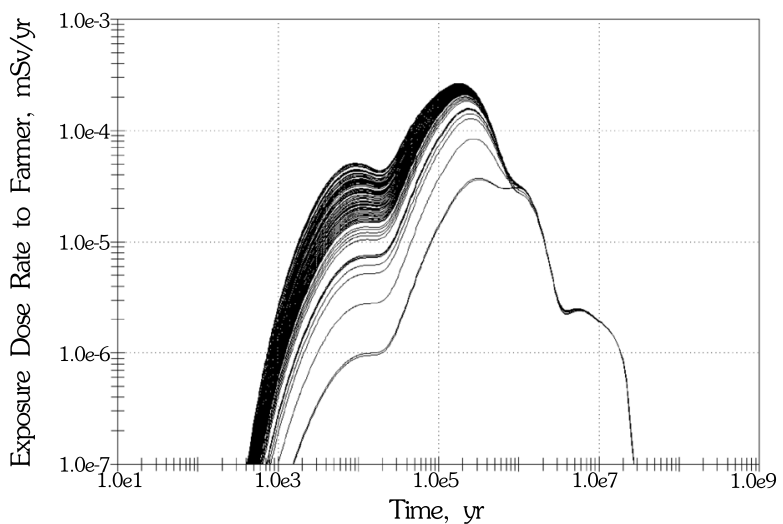

Fig. 9. All 100 realizations of the total exposure dose rate when the nuclide release rate varies, due to all the nuclides both in the metal and ceramic waste repositories to the farming exposure group.

에 도시하였다. 그림에서 $\mathrm{y}$ 축은 각 폐기물 용기의 신뢰시간 에 대한 지연 정도를 0.1 에서 10 배 사이로 보인 것이다. 정상 
Youn-Myoung Lee et al. : A Sensitivity Study on Nuclide Release from the Near-field of the Pyroprocessed Waste Repository System: Part 1. A Probabilistic Approach

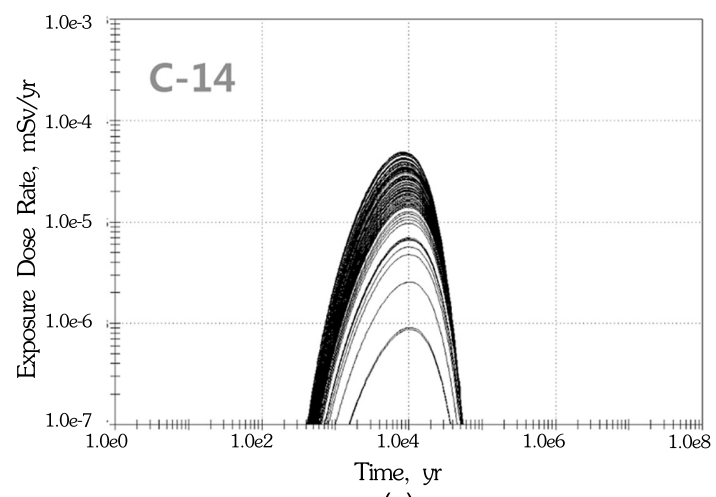

(a)

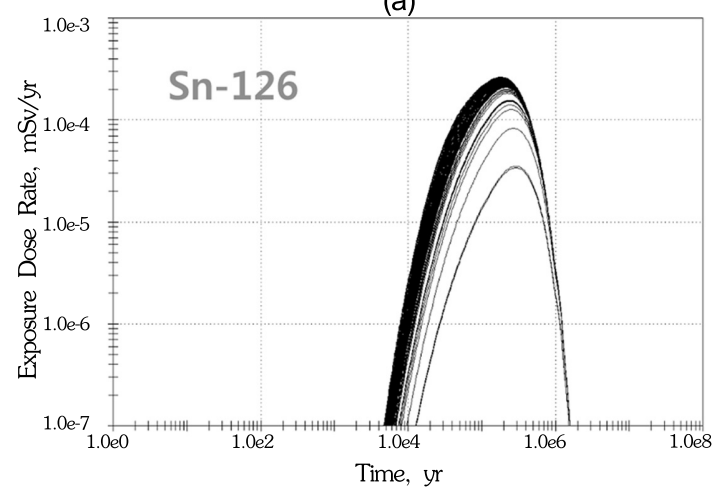

(c)

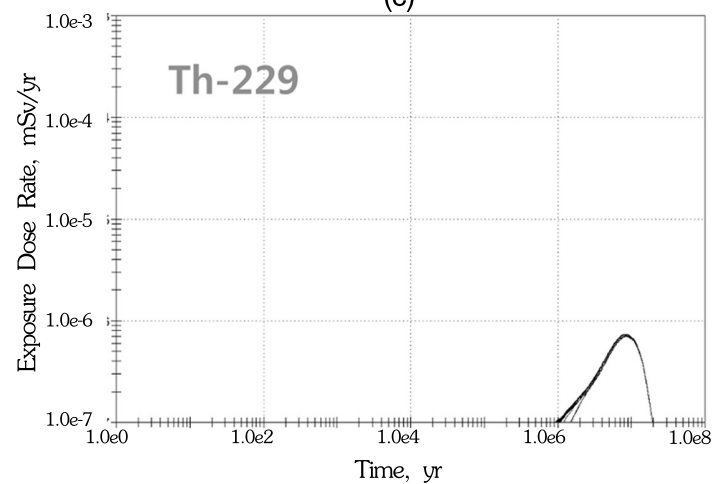

(e)

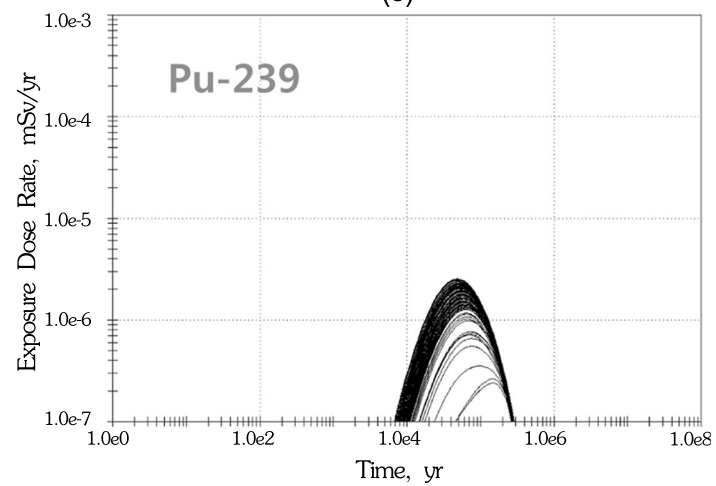

(g)

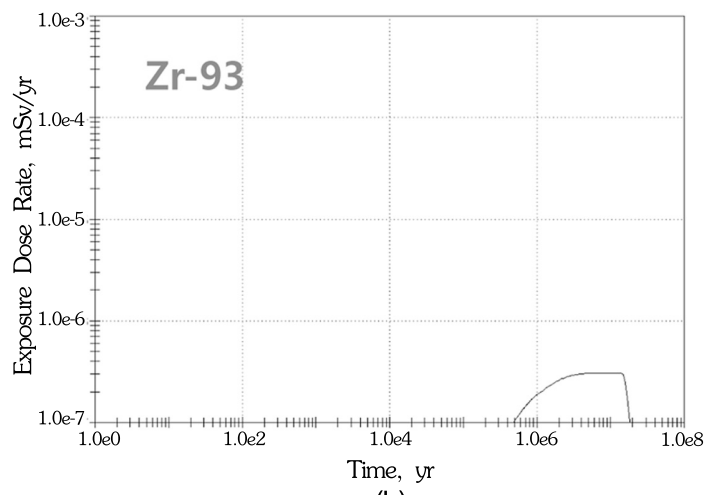

(b)

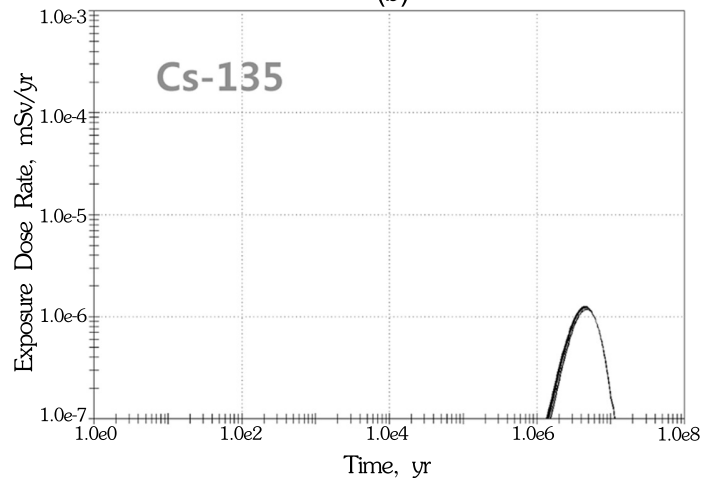

(d)

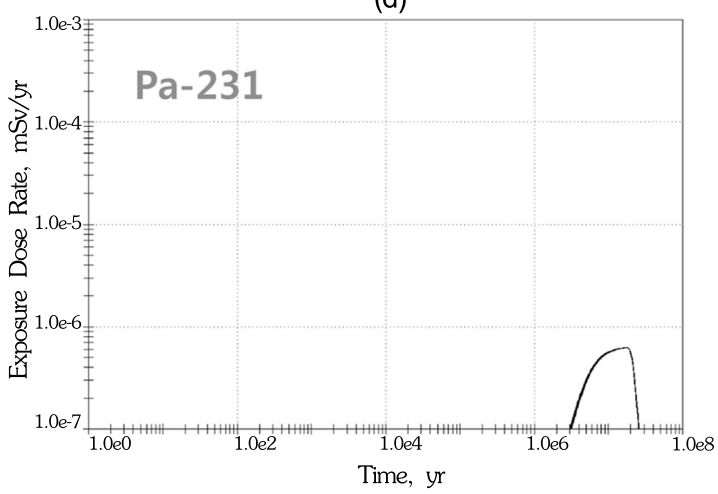

(f)

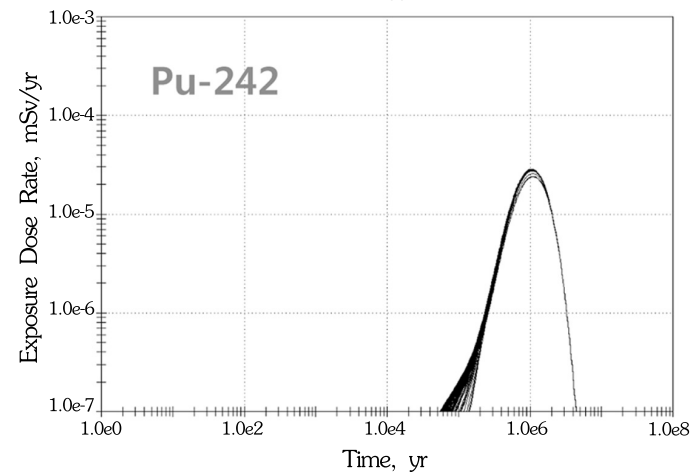

(h)

Fig. 10. Realizations of the total exposure dose rate due to each nuclide in the metal and ceramic waste repositories to the farming exposure group. 
Youn-Myoung Lee et al. : A Sensitivity Study on Nuclide Release from the Near-field of the Pyroprocessed Waste Repository System: Part 1. A Probabilistic Approach

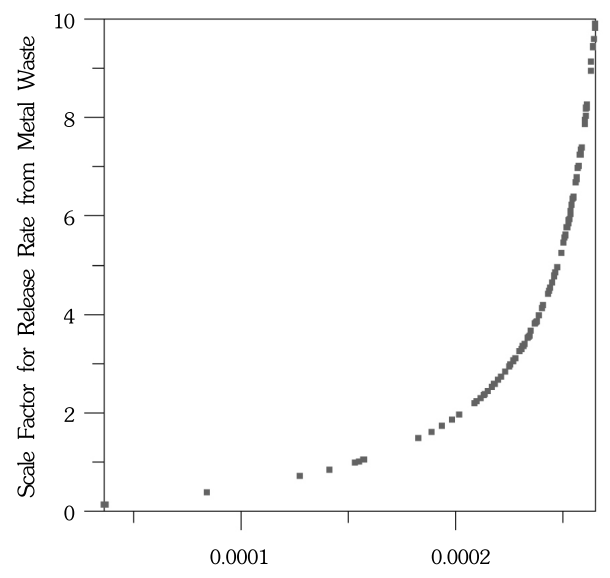

Peak Dose Rate to Farmer, mSv/yr

(a)

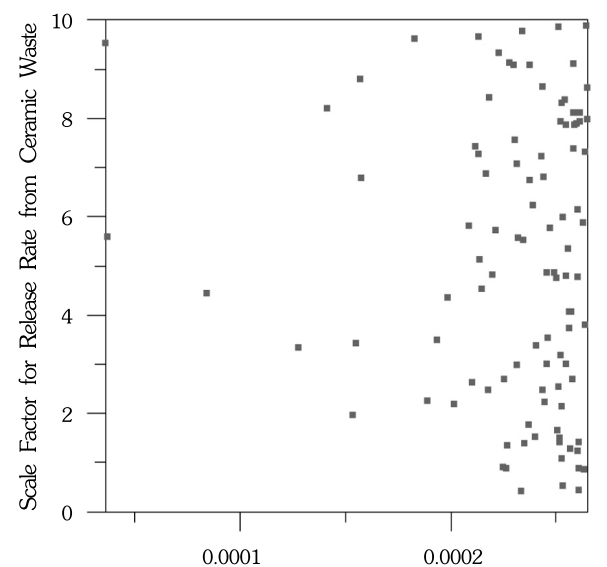

Peak Dose Rate to Farmer, mSv/yr

(b)

Fig. 11. Sensitivity of the nuclide release rate, scaled between 0.1 and 10 , from the metal (a) and ceramic (b) waste containers to the dose rate.

적인 유출률을 $10^{-5} \mathrm{yr}^{-1}$ 로 했을 때 유출률은 $10^{-6} \mathrm{yr}^{-1} \sim 10^{-4} \mathrm{yr}^{-1}$ 사이에서 변화한다는 의미가 된다.

이 역시 금속폐기물의 대해서는 핵종 유출률에 대한 피 폭 선량률의 상관관계가 서로 상당히 의존적으로 나타나는 것을 알 수 있지만(Fig. 11(a)), 세라믹 폐기물의 용기에 대한 피크 값의 민감도는 그리 높지 않게 나타나고 있는 것도 알 수 있다(Fig. 11(b)). 이 역시 세라믹 폐기물 내의 핵종이 선 량 피크치에 그리 기여하지 못하기 때문이다.

\section{3 완충재 손실도}

정상적인 완충재의 공극률인 0.41 값 대신, 금속 폐기물 과 세라믹 폐기물에 대해서 공히 Table 6에서와 같이 0과 1 사이에서 통계적으로 균등 분포를 갖는 것으로 가정하여 확 률론적 계산을 수행하여 보았다.

그 결과로서 나타난 Fig. 12에서 보면 이 경우에도 이 전의 두 인자들과 마찬가지로 연간 선량 피폭 선량의 변화 가 현저하게 나타나고 있는 것을 알 수 있다. 그러나 초기 에 변화를 보여 주던 용기 신뢰시간의 경우나 초기와 함께 피크치에 이르기까지도 변화를 보여주던 유출률과는 다소 다르게, 이러한 변화가 시간의 흐름 전반에 따라 파과 곡선 (breakthrough curve) 전체에 걸쳐 광범위하게 나타나고 있 다는 것을 알 수 있다. 이는 고려하고 있는 대부분의 핵종이 거의 모두 변화에 민감하게 기여하고 있다는 것을 암시하는 것으로 볼 수 있는데, 실제로 각 핵종별로 기여하는 연간 피
폭 선량을 도시한 Fig. 13에서 보면 반감기가 아주 길고, $\mathrm{Kd}$ 도 상대적으로 낮은 ${ }^{135} \mathrm{Cs}$ (Fig. 13(d)) 정도만 제외하고는 나 머지 핵종에 대하여 모두 적지 않은 민감도를 보여주는 것 을 알 수 있다.

Table 6. Backfill loss rate distribution

\begin{tabular}{ccc}
\hline Waste Type & $\begin{array}{c}\text { Nominal } \\
\text { (by porosity) }\end{array}$ & $\begin{array}{c}\text { Distribution } \\
\text { (by porosity) }\end{array}$ \\
\hline Metal Waste & 0.41 & Uniform $\{0,1\}$ \\
\hline Ceramic Waste & 0.41 & Uniform $\{0,1\}$ \\
\hline
\end{tabular}

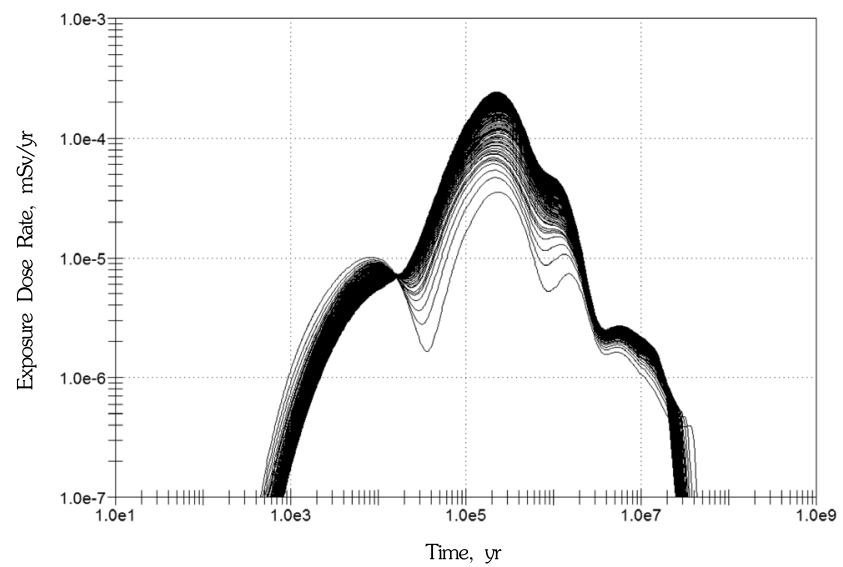

Fig. 12. All 100 realizations of the total exposure dose rate when the degree of buffer loss varies, due to all the nuclides in the metal and ceramic waste repositories to the farming exposure group. 


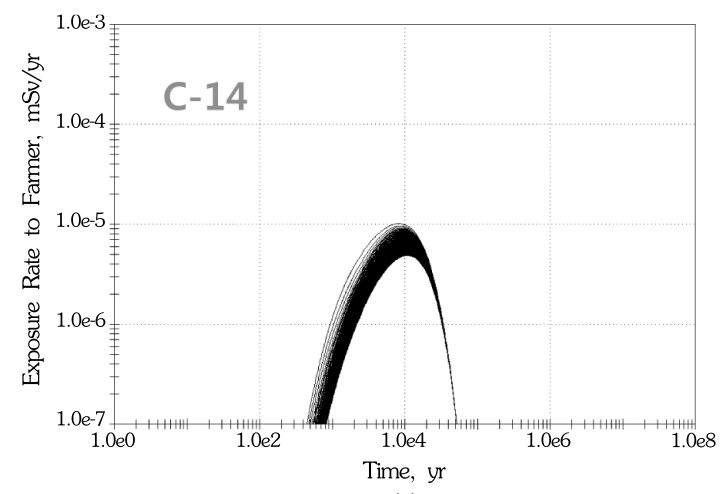

(a)

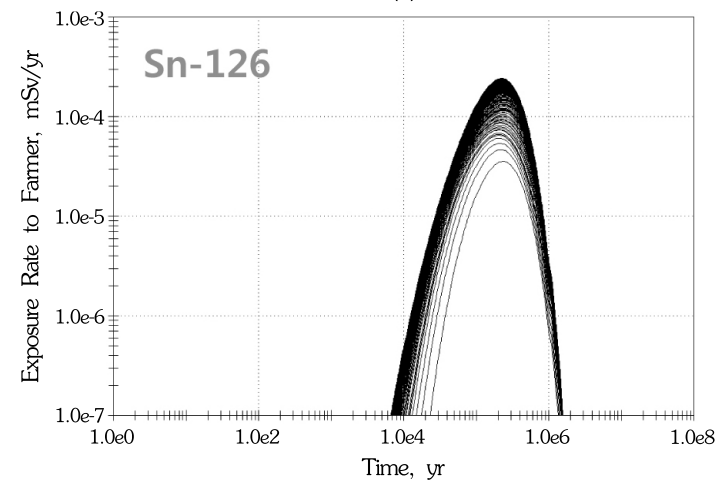

(c)

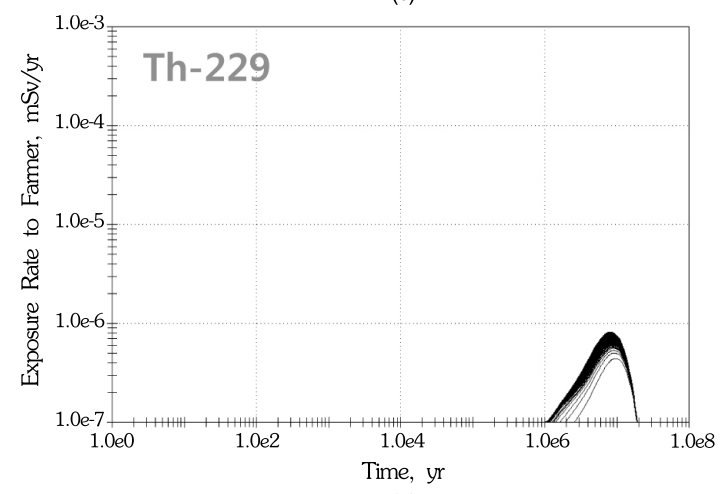

(e)

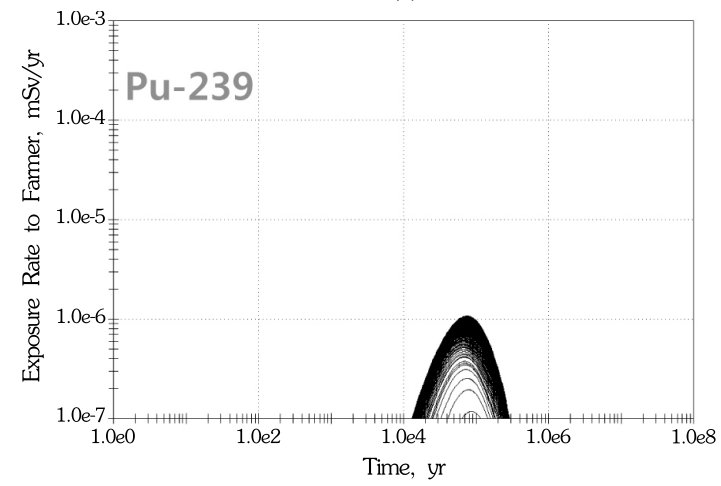

(g)

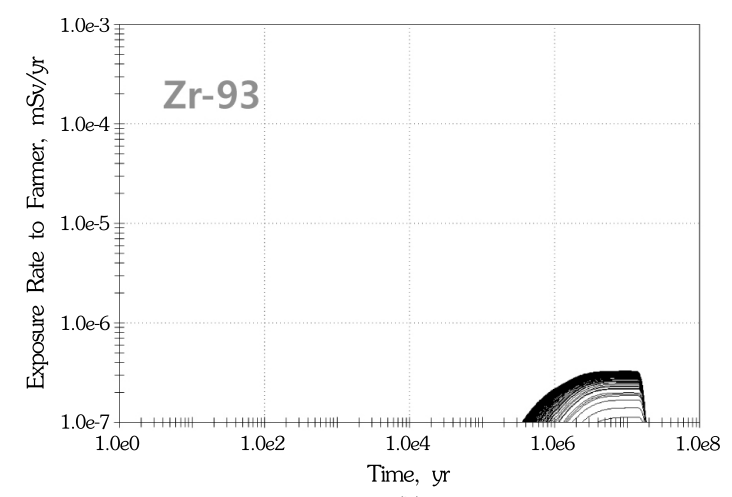

(b)

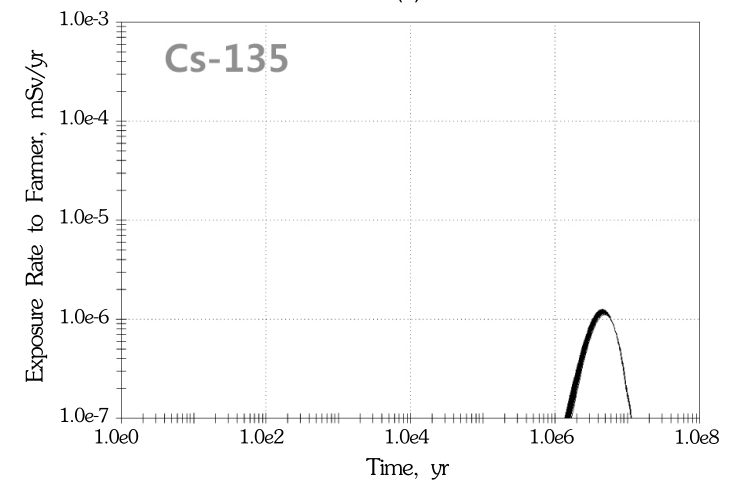

(d)

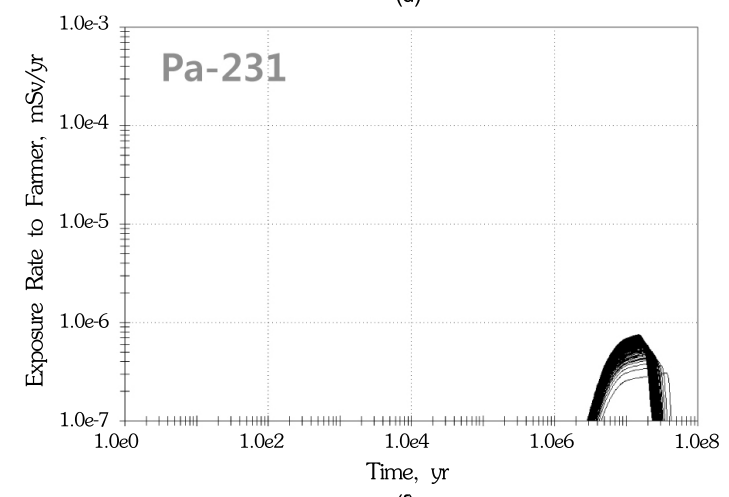

(f)

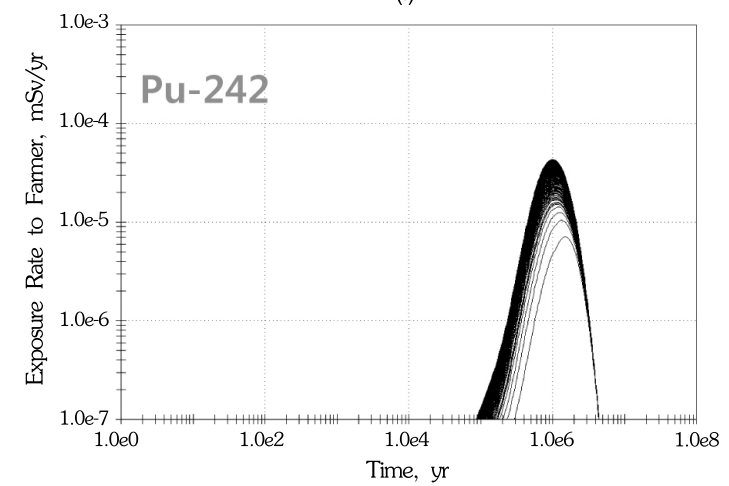

(h)

Fig. 13. Realizations of the total exposure dose rate due to each nuclide in the metal and ceramic waste repositories to the farming exposure group. 
Youn-Myoung Lee et al. : A Sensitivity Study on Nuclide Release from the Near-field of the Pyroprocessed Waste Repository System: Part 1. A Probabilistic Approach

완충재의 손실에 대한 민감도를 보기 위하여 농축피폭 집단에 주는 선량률과의 상관관계도 Fig. 14에 도시하였다. 그림에서 $\mathrm{y}$ 축은 완충재의 공극률로 나타내어 이를 완충재의 손실의 정도로서 간주하였다. 즉 공극률이 0 에 가까울 경우 완충재는 건재하다고 볼 수 있으나, 1 에 가까워지는 경우 물 리적인 완충재는 점점 손실되어가며 그 자리를 지하수가 채 워진다고 볼 수 있다.

이 역시 최대 피폭선량과의 상관관계가 상당히 의존적으 로 나타나는 것을 알 수 있다.

이제까지의 결과를 수치적으로 정량화하기 위하여 몇 가 지 척도로도 나타내 보았다. 이러한 계수에 의한 결과는 이 미 각 핵종 별로 농축 피폭 집단에 주는 피폭 선량의 결과가

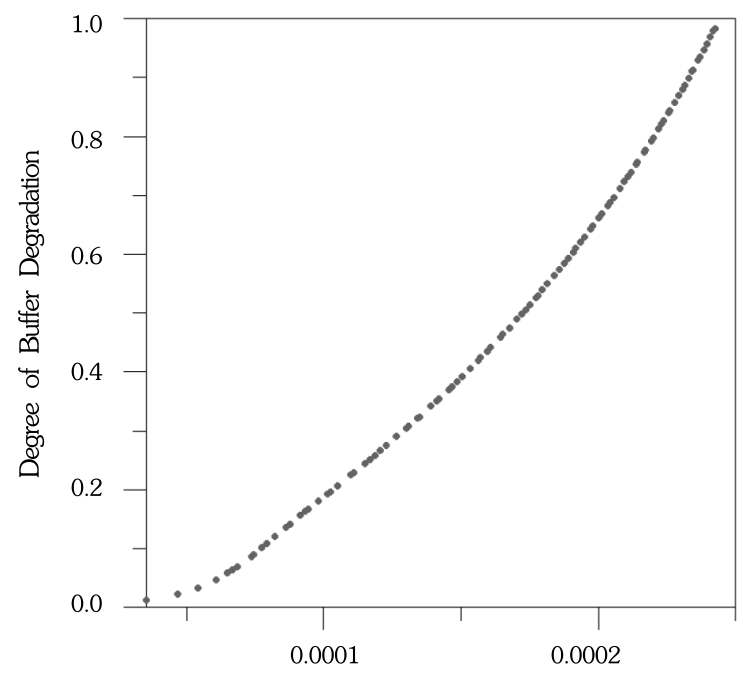

Peak Dose Rate to Farmer, $\mathrm{mSv} / \mathrm{yr}$

Fig. 14. Sensitivity of the degree of buffer degradation expressed with its porosity to the dose rate.
도식적으로 충분히 보여주고는 있지만 그 정도를 상대적인 수치로 정량화 해 주는 의미가 있다.

먼저 민감도 분석에서 사용되는 지표로서의 중요도 척도 (Importance Measure; I.M.)[10]는 0과 1사이에서 변화하는 값으로서, 이 값은 입력 변수의 값과 이에 따른 결과에 주는 영향의 정도를 가늠하는데 유효한 지표이다. 이 I.M. 은 일반 적인 상관관계계수(correlation coefficient)가 나타내주지 못 하는 비선형(nonlinear) 혹은 비단조(non-monotonic) 관계 를 인지하는데 유용하게 사용될 수 있다. 이와 별도로 상관 관계 계수, 회귀 계수(regression coefficient) 혹은 다른 입력 변수값에 대하여 계산된 결과 함께 고려하고 있는 입력 변수 영향을 모두 제외한 경우에 대하여 순수한 입력변수만의 영 향을 보고자 할 때 유용한 부분상관관계(partial correlation coefficient)는 공히 -1 (역비례)과 1(정비례)사이에서 그 영 향의 정도를 나타내 주게 된다. 이 값이 0 으로 갈수록 상관관 계가 약한 것으로 해석할 수 있다.

Table 7에 이러한 정량적 수치를 비교해 놓았는데, 용기 의 신뢰 시간과 핵종 유출률은 모두 각 폐기물 처분장을 구 분하여 나타내었다. 그러나 완충재 손실의 경우는 따로 구분 하지 않고 두 폐기물 처분장에 대하여 완충재가 동일하게 소 실되는 것으로 가정했을 때의 결과이다. 표에서 보는 대로 금속폐기물에서 유출된 핵종이 보다 큰 영향을 주고 있는 만 큼 세라믹 폐기물의 경우는 민감도가 거의 나타나고 있지 않 는 것을 알 수 있다. 이 연구를 통하여 검토된 세가지 인자 중 에서는 I.M. 과 다른 계수 상으로 완충재의 손실과 용기 신뢰 시간도 거의 동일하게 상대적으로 가장 큰 영향을 주는 것으 로 나타나고 있는 것을 알 수 있다. 그러나 금속 폐기물에서 의 민감도만으로 볼 때, 이 두 인자보다는 다소 낮긴 해도 용 기에서의 핵종의 유출률도 여전히 영향이 큰 것으로 나타나 고 있음을 알 수 있다.

Table 7. Parameter sensitivities to total dose exposure rate

\begin{tabular}{ccccccc}
\hline & Repository Type & Importance Measure & $\begin{array}{c}\text { Correlation } \\
\text { Coefficient }\end{array}$ & $\begin{array}{c}\text { Regression } \\
\text { Coefficient }\end{array}$ & Partial Coefficient \\
\hline \multirow{2}{*}{ Credit Time } & Metal & 0.868 & -0.998 & -0.998 & -0.998 \\
\cline { 2 - 7 } & Ceramic & 0.047 & -0.006 & -0.006 & -0.006 \\
\hline \multirow{2}{*}{ Release Rate } & Metal & 0.866 & 0.781 & 0.781 & -0.098 & -0.098 \\
\hline & Ceramic & 0.033 & -0.098 & 0.989 & 0.989 \\
\hline
\end{tabular}




\section{5. 결론}

A-KRS에 대하여, 폐쇄 후 처분장 근계 영역 내 처분장의 성능에 영향을 줄 수 있는 세가지 주요 설계 관련 요소를 인 지하고 핵종별로 최종 피폭선량에 대한 민감도를 조사해 보 았다. 인간 환경 내 농축 피폭 집단에 방사선 피폭을 주는 주 요한 핵종들이 처분장에서 유출되어 다양한 처분 시스템 내 매질을 이동하는 것에 관련되어 피폭 선량에 어느 정도의 영 향을 주는지 보기 위하여, 근계 영역 내 주요한 인자로서 처 분 용기의 수명, 즉 방벽으로서의 신뢰 시간, 선원항으로서 의 처분 용기에서의 연간 핵종 유출률과 그리고 처분장 주요 인공 방벽으로서의 완충재의 손실도, 이렇게 세 개를 인지하 여 이들에 대한 영향과 민감도를 검토해 보았다.

완충재의 손실과 용기 신뢰시간이 거의 동일하게 농축 피폭 집단에 대한 최종 피폭 선량에 상대적으로 가장 큰 영 향을 주는 것으로 나타나고 있는 것을 알 수 있었다. 그러나 금속 폐기물에서의 민감도만으로 볼 때, 이 두 인자보다는 다 소 낮긴 해도 용기에서의 핵종의 유출률도 여전히 영향이 큰 것으로 나타났다. 이러한 결론은 제 2 부의 결정론적 연구의 결과[9]에서도 동일하게 나타나 처분장 설계시 이러한 인자 에 대한 고려가 매우 중요할 수 있는 것으로 나타났다. 이러 한 연구 과정과 그 결과는 향후 처분장의 근계 영역 내 핵종 의 유출 및 이동 관련하여 설계 에 모범적인 방법론을 제공 할 수 있을 것으로 기대된다.

\section{감사의 글}

이 논문은 2013년도 정부(미래창조과학부)의 재원으로 한국연구재단의 지원을 받아 수행 된 연구임. (원자력연구개 발사업, No. 2012M2A8A5025589)

\section{REFERENCES}

[1] H.J. Choi and J.R. Lee, "Preliminary Conceptual Design of a Geological Disposal System for High-level Wastes from the Pyroprocessing of PWR Spent Fuels", Nuclear Engineering and Design, 241, 3348 (2011). [2] KBS, "Final Storage of Spent Nuclear Fuel", KBS-3,
Summary SKBF/KBS, Sweden (1983).

[3] Y.M. Lee and J.T. Jeong, "A-KRS GoldSim Model Verification: A Comparison Study of Performance Assessment Model", J. Korean Radioact. Waste Soc., 11(2), pp.103-114 (2013).

[4] Y.M. Lee and J.T. Jeong, "An Evaluation of an Earthquake Scenario for a Pyroprocessed Waste Repository", Progress in Nuclear Energy, 66, pp. 133-145 (2013).

[5] Y.M. Lee and J.T. Jeong, "A Deterministic Safety Assessment of a Pyro-processed Waste Repository", J. Korean Radioact. Waste Soc., 10(3), pp. 1-11 (2012). [6] Y.M. Lee and J.T. Jeong, "A Probabilistic Safety Assessment of a Pyro-processed Waste Repository", J. Korean Radioact. Waste Soc., 10(4), pp.263-273 (2012).

[7] Y.M. Lee and J.T. Jeong, "Evaluation of nuclide release scenarios for a hypothetical LILW repository", Progress in Nuclear Energy, 53, pp.760-774 (2011).

[8] Y.M. Lee and Y.S. Hwang, "A GoldSim Model for the Safety Assessment of an HLW Repository", Progress in Nuclear Energy, 51, 746 (2009).

[9] Y.M. Lee and J.T. Jeong, "A Sensitivity Study on Nuclide Release from a Pyroprocessed Waste Repository System: Part 2. A Deterministic Approach", J. Korean Radioact. Waste Soc., 12(1), pp.37-43 (2014).

[10] GoldSim Contaminant Transport Module, User's Guide, Version 5, GoldSim Technology Group, Seattle, USA, 2006.

[11] Report of an IAEA International Review Team, An International Peer Review of the Programme for the Deep Geological Disposal of High Level Radioactive Waste from Pyro-Processing in the Republic of Korea, IAEA, September 2013. 